\title{
O Sanctus de Alberto Nepomuceno: um Caso de Intertextualidade Musical
}

\section{Alberto Nepomuceno's Sanctus: a Case of Musical Intertextuality}

\section{Thiago Plaça Teixeira}

Universidade Tecnológica Federal do Paraná

thiagoplacateixeira@gmail.com

\section{Norton Dudeque}

Universidade Federal do Paraná

nortondudeque@gmail.com

Resumo: O presente artigo se propõe a analisar a obra Sanctus, da Missa em Ré menor (1915) de Alberto Nepomuceno (1864-1920) e demonstrar as relações de intertextualidade musical entre ela e o Sanctus da Missa Te Deum Laudamus (1899) de Lorenzo Perosi (1872-1956). Uma análise comparativa entre os dois Sanctus demonstra que a obra de Nepomuceno se apresenta como uma paráfrase da obra de Perosi. Há semelhanças entre as duas obras quanto à estrutura formal, alternância das texturas, contorno melódico e quanto aos procedimentos harmônicos empregados pelos compositores.

Palavras-chave: musicologia; Alberto Nepomuceno; música sacra; intertextualidade musical.

\begin{abstract}
This article aims to analyze the Sanctus of the Mass in D minor (1915) composed by Alberto Nepomuceno (1864-1920) and to demonstrate intertextual relationships between this work and the Sanctus of the Missa Te Deum Laudamus (1899) composed by Lorenzo Perosi (1872-1956). A comparative analysis between the two Sanctus demonstrates that Nepomuceno's work seems to be a paraphrase of Perosi's work. There is similarity between the works in what concerns formal structure, texture alternation, melodic contours and harmonic procedures employed by the composers.
\end{abstract}

Keyw ords: musicology; Alberto Nepomuceno; sacred music; musical intertextuality. 


\section{1 - Contexto:Alberto Nepomuceno e a Música Sacra}

Alberto Nepomuceno é considerado pela historiografia musical um expoente da música erudita do Brasil no período marcado pelo início do regime republicano, isto é, no final do século XIX. De fato, Nepomuceno exerceu intensa atividade musical em sua época, seja pelo fecundo trabalho à frente do Instituto Nacional de Música, seja por seu trabalho como compositor ${ }^{1}$.

Entre os muitos gêneros musicais aos quais Nepomuceno se dedicou, iremos limitar a atenção do presente artigo à música sacra. O sentido de música sacra, neste caso, é de música destinada a "revestir de adequadas melodias o texto litúrgico" no culto público da Igreja Católica Apostólica Romana. O contato de Nepomuceno com este gênero musical se deu fundamentalmente em quatro âmbitos:

1) Na sua formação musical na Europa, especialmente na Schola Cantorum de Paris, uma instituição de ensino musical fundada em 1894 por Charles Bordes (1863-1909), Alexandre Guilmant (1837-1911) e Vincent d'Indy (1851-1931). Os três fundadores tinham o mesmo ideal de recuperar a música religiosa gregoriana e palestriniana. O ensino promovido pela Schola Cantorum consistia em cursos em diversas áreas: canto gregoriano, órgão, piano, harmonia, contraponto etc. De Vincent d'Indy, em particular, sabe-se que "inspirou suas obras nesse canto [gregoriano], integrando-o à disciplina de análise e composição musical que ele próprio ministrava em seu célebre conservatório particular significativamente chamado de Schola Cantorum, onde também lecionou o musicólogo gregorianista Amédée Gastoué" (Viret, 2015, p. 60).

2) Na sua atuação em prol da recuperação da obra sacra do compositor brasileiro Pe. José Maurício Nunes Garcia (1767-1830). Entre 1896 e 1898, por exemplo, Nepomuceno trabalhou na redução (para órgão, piano e harmonium) de algumas obras do Pe. José Maurício: Requiem, Missa em si bemol e Missa de Santa Cecília. Por ocasião das cerimônias de inauguração da famosa Igreja da Candelária, no Rio de Janeiro, em 10 de Julho de 1898, coube a Nepomuceno a regência da Missa de Santa Cecília (Goldberg, 2006).

3) Na sua atuação em prol da regulamentação da música sacra na arquidiocese do Rio de Janeiro. Em 1895, o crítico musical do Jornal do Commercio, Rodrigues Barbosa (1857-1939) iniciou uma campanha para restaurar a música sacra católica no Brasil. Nepomuceno mostrou-se ativo em tal movimento, vindo a ser membro da Comissão de Música Sacra, nomeada em 1898 pelo Arcebispo Dom Joaquim

\footnotetext{
1 “Nepomuceno foi o vulto mais importantena música brasileira duranteo período de sua vida. Realizou um trabalho sério e fecundo como virtuose do piano e do órgão, como regente, professor e, sobretudo, como compositor. Com toda razão é considerado o Fundador da Música Brasileira" (Kiefer, 1976, p. 114).
} 
Arcoverde de Albuquerque Cavalcanti (1850-1930) para estudar e elaborar um regulamento para a música sacra no Rio de Janeiro (Goldberg, 2006).

4) Nas suas próprias composições musicais. O catálogo das obras de Alberto Nepomuceno (Corrêa, 1996) indica dez peças musicais elaboradas sobre algum tipo de texto litúrgico católico:

\begin{tabular}{lll}
\hline \multicolumn{1}{c}{ Obra } & \multicolumn{1}{c}{ Formação } & \multicolumn{1}{c}{ Data } \\
\hline Miserere mei & 2 vozes à capella & 1896 \\
\hline O salutaris hostia & Canto e Harmonium & $1897($ ?) \\
\hline Tantum ergo & Coro feminino à capella & 1898 \\
\hline Ingemisco & Canto e Piano & $1899($ ?) \\
\hline Panis angelicus & 2 vozes e Harmonium ou Órgão & 1909 \\
\hline Ecce panis angelorum & 2 vozes e Harmonium ou Órgão & 1911 \\
\hline O salutaris hostia & Coro para vozes femininas e Harmonium & 1911 \\
\hline Tantum ergo & Coro e Harmonium ou Órgão & 1911 \\
\hline Ave Maria & Canto e Piano & 1911 \\
\hline Missa & 2 vozes e Órgão & 1914 \\
\hline
\end{tabular}

Tabela 1 - Obras sacras de Alberto Nepomuceno (Fonte: Corrêa, 1996)

Entre tais composições, nota-se que há apenas uma $M i s s a^{2}$, cuja edição, pela Bevilacqua \& C., apresenta o seguinte título: "Missa duabus vocibus aequalibus quam in honorem Virginis Immaculatae concinnavit et Eminentissimo Domino Cardinali Arcoverde dicavit. Die 26 Octobris Anni 1915. A. Nepomucenus" [Missa a duas vozes iguais composta em honra da Virgem Imaculada e dedicada ao Sr. Eminentíssimo Cardeal Arcoverde. Dia 26 de Outubro de 1915. A. Nepomuceno]. Duas coisas merecem especial consideração: a homenagem a Nossa Senhora e a dedicatória ao Cardeal Arcoverde.

Em primeiro lugar, na partitura manuscrita da Missa, na última página, consta a assinatura de Nepomuceno e a data de 08 de Dezembro de 1914, juntamente com a frase "Deus seja louvado". A data de 08 de Dezembro, no calendário litúrgico da Igreja Católica, é a festa da Imaculada Conceição da Bemaventurada Virgem, dia santo de guarda ${ }^{3}$. Possivelmente por razões de especial devoção a Nossa Senhora, quis o compositor finalizar sua obra em data tão solene e nomear a Missa em decorrência disto.

\footnotetext{
2 No Catálogo é citada uma outra Missa, desaparecida.

3 “Os dias que devem ser santificados de modo especial são, além dos domingos, as seguintes festas: Natal, Circuncisão, Epifania, Ascensão, Corpo de Deus, Imaculada Conceição, Assunção, S. José (19 de março), S. Pedro e S. Paulo, Todos os santos. [...] A santificação dos domingos e dias de guarda consistena abstenção de trabalhos servis ena assistência à missa" (Jone, 1943, p. 149, grifo nosso).
} 
Em segundo lugar, a data de 26 de Outubro de 1915 marcou o jubileu episcopal, isto é, o aniversário de vinte e cinco anos da sagração episcopal ${ }^{4}$ de Dom Joaquim Arcoverde, então arcebispo do Rio de Janeiro e primeiro dos prelados sul-americanos a se tornar cardeal. Na sobredita data, o próprio cardeal celebrou uma solene missa pontifical ${ }^{5}$ na Catedral Metropolitana do Rio de Janeiro, com a assistência de Bispos e Arcebispos de todo o Brasil, sendo executada, então, a Missa que Nepomuceno dedicou-lhe:

Assumiu as proporções de uma verdadeira apoteose a festa ontem celebrada nesta cidade em sinal de regozijo pela data do jubileu episcopal de D. Joaquim Arcoverde. A população católica deste arcebispado, apesar de ser um dia útil, representada pelo que de melhor possui a nossa sociedade, afluiu em massa a levar a seu amado pai espiritual e pastor o preito de sua homenagem. [...] Com todo o imponente cerimonial litúrgico do rito católico, celebrou-se na catedral a solene missa cantada, oficiando pontificalmente Sua Eminência [...]. O vasto templo regurgitava de fiéis, estando completamente cheias a nave e tribunas.

A Schola Cantorum Santa Cecília, dando desempenho às partes musical e coral, apresentou magnífico conjunto, executando, sob a regência de seu diretor, cônego Alpheu Lopes de Araújo, um magnífico programa assim organizado: Prelúdio, do maestro Francisco Braga; hino Ecce Sacerdos, de Homero Barreto; Andante, de Henrique Oswald; Missa, do maestro Alberto Nepomuceno, que a compôs especialmente para a solenidade do Jubileu e ofereceu ao Exmo. cardeal; Ofertório, de Arnaud de Gouveia, e Elevação, de Glauco Velasquez. (O Paiz, Rio de Janeiro, 27/10/1915, grifo nosso).

Digno de nota é o fato de a Missa de Nepomuceno ter sido executada pela Schola Cantorum Santa Cecília, conduzida pelo Pe. José Alpheu Lopes de Araújo $^{6}$, o qual teve grande atuação na área da música sacra na Arquidiocese do

\footnotetext{
4 “Bispos são os sucessores dos a póstolos, de quem por direito divino herdaram o tríplice poder de instruir, de santificar e de governar uma porção do rebanho de Cristo. [...] Os bispos, pela sagração, que é a cerimônia mais sugestiva da liturgia católica, são elevados ao cume do sacerdócio cristão, e em sua alma se imprime o caráter episcopal, em virtude do qual são dotados do sumo poder de Ordem, que contém o poder de confirmar e de ordenar" (Parente, 1955, p. 262). 5 "Missa pontifical é a missa celebrada pelos bispos ou dignitários privilegiados revestidos dos paramentos pontificais. Pode ser solene ou rezada. [...] A missa é dita "cantada" quando o celebrante canta as partes que lhe correspondem no missal. É dita "solene" quando é uma missa "cantada" com ministros sacros, istoé, quando o sacerdote é assistido por diácono e sub-diácono (Reus, 1944, p.267).

6 "O Pe. José Alpheu Lopes de Araújo, cónego da Catedral Metropolitana, Mestre de Capela do Cabido e (1924) professor de órgão e harmónio do Instituto Nacional de Música, ordenado em 1894 no Colégio Pio Latino em Roma, organizou, logo que voltou ao Brasil, um notável coro de meninos na Matriz de Santana, dando um exemplo prático de música sacra correta" (Schubert, 1980. p.22). Sobre a ativa participação que teve a Schola Cantorum Santa Cecília em cerimônias religiosas na Catedral do Rio de Janeiro, dizia um colunista do jornal A União em 16/05/1915: “Na Catedral, nas missas pontificais, tenho ouvido e apreciado a Schola Cantorum Sanctae Ceciliae,
} 
Rio de Janeiro na primeira metade do século XX. Frequentes menções em periódicos da época denotam sua intensa atividade à frente da Schola Cantorum em cerimônias religiosas, inclusive na Catedral. Destacamos aqui a coluna de Carlos Mayer no Correio de Manhã de 28 de Janeiro de 1907, que relata:

O reverendo padre Alpheu Lopes há mais de ano fundando a Schola Cantorum S. Caeciliae, deu-se corpo e alma à restauração da música sacra a qual consiste em restabelecer o canto gregoriano em toda a sua grandeza e majestade de expressão calma e religiosa.

Na paróquia de Sant'Anna, lá na Cidade Nova, à custa de enormes esforços e sacrifícios pecuniários, conseguiu reunir um núcleo de cantores ministrando-lhes os conhecimentos necessários à inter pretação e execução do canto instituído por S. Gregório.

Lutando com a indiferença do nosso meio social, e graças à paternal proteção do nosso amado chefe, o eminentíssimo Cardeal Arcoverde, obteve que na Catedral metropolitana, fosse substituída a música lírica, a música de concertos religiosos, pela outra mais séria, mais adequada ao culto divino.

Poucas, bem poucas paróquias, entretanto, aceitaram a inovação. $\mathrm{O}$ hábito enraizado, estranho, de oferecerem festividades cerzidas sobre rebotalhos de obras teatrais, com grande orquestra e solistas dramáticos, ou de estilo condenado pela comissão pontifícia, é barreira insuperável aos excelentes desejos do padre Alpheu, no sentido de alargar a esfera benéfica do canto sacro, a outras paróquias da arquidiocese. [...]

Contudo, o virtuoso padre, a cujos ombros tomou o espinhoso encargo, não desanima; cheio de fé no seu ideal e esperançado na eficaz e paternal bondade do príncipe da Igreja que rege a nossa arquidiocese, vai prosseguindo na santa cruzada contra os profanadores do templo.

Não surpreende, pois, que em uma solenidade tão importante à Igreja no Brasil, tal como foi o jubileu episcopal do Cardeal Arcoverde, coubesse justamente à Schola Cantorum do Pe. Alpheu a execução da Missa de Nepomuceno. Além disso, sabe-se que no ano seguinte a mesma Missa teria sido novamente executada pelo mesmo grupo musical por ocasião de outra importante data comemorativa de D. Arcoverde, a saber, o aniversário de sua transferência da Diocese de São Paulo para a Arquidiocese do Rio de Janeiro:

dirigida pelo revmo. Cônego Alpheu Lopes de Araújo". Uma notícia da mesma época faz referência a uma Missa em que se fizeram presentes Nepomuceno e Pe. Alpheu: "O ilustre maestro Alberto Nepomuceno, diretor do Instituto Nacional de Música, que acaba de regressar de Roma ... fez anos ontem. Admiradores amigos discípulos do exímio musicista fizeram rezar pelo faustoso acontecimento missa em ação de graça, na matriz da Glória. A 'Schola Cantorum Santa Cecília', dirigida pelo cônego Alpheu, cantou o Kyrie de Botegliero" (Correio da manhã, Rio de Janeiro, 07/07/1915). Villa-Lobos chegou a dedicar algumas de suas obras religiosas "ao amigo Cônego Alpheu": Marcha religiosa no 3 (1916), O Salutaris (1916) e O Salutaris hostia (1915) (cf. Museu Villa-Lobos, 2009).

\section{MUSICA THEORICA}




\begin{abstract}
Deveria realizar-se, pela manhã, na Catedral Metropolitana, missa pontifical, sendo nessa ocasião executada, pelo Schola Cantorum Santa Cecília, sob a competente regência do cônego José Alpheu Lopes de Araújo, a bela missa de Nossa Senhora da Conceição, oferecida pelo maestro Alberto Nepomuceno à sua eminência, por ocasião do seu jubileu episcopal.

A missa deveria ter sido executada por um grande número de vozes, com acompanhamento e harmonium, e quinteto de cordas, em que tomaria parte um grupo escolhido de professores do Centro Musical do Rio de Janeiro.

A morte, porém, do bispo D. Fernando Monteiro fez com que não se realizassem essas comemorações festivas.

O Sr. D. Joaquim Arcoverde, permaneceu no palácio São Joaquim, recolhido aos seus aposentos (A Notícia, Rio de Janeiro, 24-25/03/1916, grifo nosso).
\end{abstract}

Em linhas gerais, tal é o contexto histórico local em que se dá a composição e execução da Missa de Alberto Nepomuceno.

\title{
2 - O Motu proprio de São Pio X e a obra do Pe. Lorenzo Perosi
}

A atuação de Alberto Nepomuceno no âmbito da música sacra coincide cronologicamente com um período de contundente intervenção das autoridades da Igreja na regulamentação das músicas executadas nas liturgias católicas. Em 1884, por exemplo, a Sagrada Congregação dos Ritos emite a Ordinatio quoad sacram musicen; e em 1894, novas normas. Em 1903, finalmente, tem-se o famoso Motu proprio ${ }^{7}$ Tra le sollecitudini do Papa São Pio X, ao qual o próprio Pontífice chamou de "código jurídico de música sacra":

Para que ninguém doravante possa alegar a desculpa de não conhecer claramente o seu dever, e para que desapareça qualquer equívoco na interpretação de certas determinações anteriores, julgamos oportuno indicar com brevidade os princípios que regem a música sacra na funções do culto e recolher num quadro geral as principais prescrições da Igreja contra os abusos mais comuns em tal matéria. E por isso, de própria iniciativa e ciência certa, publicamos a nossa presente Instrução; será ela como que um código jurídico de música sacra; e, em virtude da plenitude de nossa autoridade apostólica, queremos que se lhe dê força de lei, impondo a todos, por este nosso quirógrafo, a sua mais escrupulosa observância (Documentos sobrea música litúrgica, 2005, p. 15).

Em tal documento, o Papa determina que a música sacra deve possuir três qualidades próprias da liturgia: santidade, delicadeza das formas e

\footnotetext{
7 Designa-se por Motu Proprio o tipo de documento cujas decisões são decididas pessoalmente pelo Papa, ou seja, sem o conselho de Cardeais ou outros, mas simplesmente por r azões que a ele são suficientes (cf. The Catholic Encyclopedia).
}

\section{MUSICA THEORICA}


universalidade. Tais atributos, segundo o pontífice, encontram-se em grau sumo no Canto Gregoriano, a tal ponto que "uma composição religiosa será tanto mais sacra e litúrgica quanto mais se aproxima no andamento, inspiração e sabor da melodia gregoriana, e será tanto menos digna do templo quanto mais se afastar daquele modelo supremo" (Documentos sobre a música litúrgica, 2005, p. 16). Tais qualidades verificam-se também na polifonia clássica, "especialmente na da Escola Romana, que no século XVI atingiu a sua maior perfeição com as obras de Pedro Luís de Palestrina" (Ibidem). Quanto à música moderna, a Igreja a admite na Liturgia "visto que apresenta composições de tal qualidade, seriedade e gravidade que não são de forma alguma indigna das funções litúrgicas [...] mas deverá vigiar-se [...] para que as composições musicais de estilo moderno [...] não tenham coisa alguma profana, não tenham reminiscências de motivos teatrais e não sejam compostas [...] sobre o andamento das composições profanas" (p. 17).

No que concerne ao estilo musical a que os compositores se atinham na elaboração da música sacra neste mesmo período, isto é, entre o final do século XIX e o início do século XX, pode-se afirmar que se impôs em diferentes países de tradição católica a tendência de se considerar o canto gregoriano e a antiga polifonia clássica como pilares da música litúrgica, o que causou, simultaneamente aos avanços nas pesquisas musicológicas, uma marcante ruptura entre a música da Igreja e as correntes artísticas contemporâneas:

Paralelamente à sinfônica e dramática música sacra no século XIX, emergiu um novo estilo, baseado na história e comprometida com exigências litúrgicas. Na medida em que retornava a modelos antigos, rompeu com as técnicas sinfônicas contemporâneas e, ao mesmo tempo, tentou ajustar e influenciar a música contemporânea (Fellerer, 1979, p. 182).

Trata-se, em suma, do movimento chamado Cecilianismo ${ }^{8}$, o qual, ainda que especialmente forte nos países germânicos, lançou raízes também em outros países europeus, ${ }^{9}$ tendo na Itália como destacados representantes os músicos

\footnotetext{
8 “Um movimento do século XIX, centrado na Alemanha, objetivando a reforma da música sacra Católica. Reagindo ao liberalismo do Iluminismo, os Cecilianistas visavam restaurar o sentimento religioso tradicional e a autoridade da Igreja. Consideravam 'verdadeira e autêntica música sacra' como sendo aquela que é subordinada à liturgia, e a inteligibilidade das palavras e da música como sendo mais importantes que a individualidade artística. O movimento tirou seu nome de Santa Cecília, a padroeira da música sacra e da Congregazioni Ceciliani, do século XV. Esta última inspirou a formação de Caecilien-Bündnisse (Ligas Cecilianas) em Munique, Passau, Viena e out ras localidades no século XVIII" (Gmeinwieser, 2001).

9 “Em 1868, três anos após ter clamado pela reforma da música sacra em Der Zustand der katholischen Kirchenmusik zunächst in Altbayern, Witt fundou a Allgemeiner Deutscher Cäcilienverein por ocasião do encontro de Católicos em Bamberg. Sancionado pelo Papa Pio IX em 1870, inspirou a fundação de organizações semelhantes na Holanda (por Diepenbrock e outros), Itália
} 
Giovanni Tebaldini (1864-1952), Luigi Bottazzo (1845-1924) e Lorenzo Perosi $(1872-1956)^{10}$. Especial menção merece Perosi, que, dotado de reconhecido talento musical e colocado, durante décadas, no renomado cargo de Maestro Perpetuo della Capela Sistina, no Vaticano, gozou de grande prestígio junto às autoridades da Igreja e de imensa popularidade no meio artístico-musical de sua época. Suas obras litúrgicas e sua fama chegaram ao Brasil e não deixaram de influir na produção musical sacra em nosso País. Até mesmo Villa-Lobos (1887-1959), pertencente já a uma geração posterior à de Nepomuceno e particularmente zeloso pela pretensa originalidade de suas obras, reconhece Perosi como referência em termos de música sacra, tal como relata o escritor Manuel Bandeira (1886-1968) no Jornal do Brasil de 16 de Julho de 1958:

Havia muito tempo que eu não tinha o prazer de abraçar o nosso grande Villa,
que é como costumamos chamar, os seus íntimos, Heitor Villa-Lobos. Sabendo
que ele estava de volta à terrinha, fui logo procurá-lo no seu apartamento da Rua
Araújo Porto Alegre. Encontrei-o como ele é sempre encontrado a qualquer hora
do dia ou da noite: trabalhando.
Desta vez estava trabalhando no Magnificat que lhe foi encomendado pelo
Vaticano.
- Então, bichão, agora na música sacra?
- Agora? Você se esquece que eu já escrevi quatro missas, uma de Requiem, que
tenho dois volumes de motetos, e muitas outras coisas avulsas.
Fiquei encabulado. Mas quem já deu a volta do Villa?
No outro dia Mariuccia Jacovino disse-me que o Quarteto do Rio de Janeiro
estava ensaiando o $16^{\circ}$ quarteto do Villa. O último de que eu tinha notícia era o
oitavo. E me lembrava da conversa quea propósito dele tivera com o compositor.
- A verdadeira sonoridade do quartetoéa de Haydn, dissera-me Villa. Beethoven
é demasiado egocêntrico: é ele, ele e mais nada. Beethoven, sinfonia; Haydn,
quarteto.

(Tebaldini, Perosi, Bottazzo), Bélgica (Tinel), Polônia, Boêmia, Hungria, Suíça e América do Norte" (Gmeinwieser, 2001).

${ }^{10}$ Nasceu em Tortona, na Itália, em 1872 e morreu em Roma, em 1956. Iniciou seus estudos musicais com seu pai, Giuseppe Perosi (1849-1908), que era Maestro di Cappela da Catedral de Tortona. Estudou com Michele Saladino no Conservatório de Milão, onde diplomou-se em 1892. Após seus estudos em Milão, passou um ano de estudo na Kirchenmusikschule, em Regensburg, na Alemanha, com Franz Xaver Haberl, grande musicologista, pioneiro editor das obras de Palestrina e Lassus. Em seguida, assumiu o trabalho de professor e diretor de música sacra em Imola, na Itália, entre 1892 e 1894, ano em que visitou a famosa Abadia de Solesmes, na França, onde estudou canto gregoriano com Dom Mocquereau e Dom Pothier. Entre 1894 e 1907, Perosi assumiu o cargo de Maestro da Capella Marciana na Basílica de São Marcos em Veneza, cujo então Patriarca era Dom Giuseppe Sarto, futuro Papa São Pio X, com quem Perosi cultivou grande amizade e por quem foi ordenado Sacerdote em 1895. Em 1898, Perosi foi indicado para o posto de Maestro Perpetuo della Capela Sistina, no Vaticano, cargo que manteve, ainda que com algumas interrupções, até sua morte, em 1956. Particularmente famoso por seus Oratórios, Perosi também compôs várias Missas e obras sacras menores, além de música secular, como, por exemplo, concertos e peças para música de câmara (Ciampa, 2006).

\section{MUSICA THEORICA}

Revista da Associação Brasileira de Teoria e Análise Musical Journal of the Brazilian Society for Music Theory and Analysis @ TeMA 2016 - ISSN 2525-5541 
E na música sacra quem é que é? perguntei agora, que ouvia falar do Magnificat para o Vaticano.

Villa sorriu: - Perosi!

Mas eu: - E Palestrina?

- Palestrina, Vitoria são muito rigorosos, muito rígidos. Sabes que eu sou pecador: tenho pecado muito! (Jornal do Brasil, Rio de Janeiro, 16/07/1958, grifo nosso).

Na época da atuação de Nepomuceno no Rio de Janeiro, os periódicos cariocas frequentemente traziam notícias sobre a repercussão da obra de Perosi na crítica musical da época ${ }^{11}$. Também se nota nos programas musicais das solenidades religiosas deste período a execução de obras litúrgicas de Perosi ${ }^{12}$.

De nossa parte, entendemos que também a obra sacra de Nepomuceno evidencia a filiação estilística ao Cecilianismo e, em alguns aspectos, uma influência direta da música de Perosi. O Sanctus da Missa de Nepomuceno, por exemplo, apresenta claramente determinadas categorias de intertextualida de ${ }^{13}$ com um Sanctus de uma Missa de Perosi, sobretudo na utilização da textura musical como elemento gerador do esquema formal.

\footnotetext{
11 “Os jornais italianos falam com entusiasmo de uma oratória Ressurreição de Lázaro, cuja música é escrita por Perosi, um padre que conta apenas 25 anos. Segundo os críticos, a música de Perosi coloca o seu autor a par dos mestres do gênero - Palestrina, Haendel, Bach e Haydn" (A Notícia, Rio de Janeiro, 29-30/11/1898).

12 “Revestiu-se de máxima solenidade a cerimônia da abertura do segundo Congresso Católico Brasileiro, ontem realizada. [...] O majestoso templo da Candelária estava, às 11 1/2 da manhã, repleto de famílias e cavalheiros, quando sua eminência o Cardeal D. Joaquim Arcoverde de Albuquerque Cavalcanti, Arcebispo do Rio de Janeiro, chegou àquela matriz [...]. A Schola Cantorum Santa Cecília, sob a regência do Revmo. Padre Alpheu Lopes de Araújo, executou o seguinte programa: Missa Eucharistica, do padre Lourenço Perosi, para contraltos, primeiros tenores, segundos tenores e baixos" (Correio da Manhã, Rio de Janeiro, 27/07/1908).

${ }^{13}$ Intertextualidade é um termo cunhado pela crítica literária Júlia Kristeva que designa uma multiplicidade de relações entre textos: citação, empréstimo, compartilhamento de convenções e estilos etc. Considera-se, assim, a obra literária não como entidade independente ou forma de comunicação, mas sim como uma resposta a textos preexistentes. Já nos anos 80 do século XX a intertextualidade encontrou adeptos entre musicólogos, que, inicialmente, procuravam se valer de tal conceito para tratar de semelhanças en tre obras musicais cuja conexão histórica não podia ser inequivocamente demonstrada (Burkholder, 2001).
}

\section{MUSICA THEORICA}




\section{3 - O Sanctus na Missa}

O Sanctus é uma das partes do chamado Ordinário ou Partes fixas da Missa católica $^{14}$. É executado no momento mais solene da Missa, a saber, imediatamente antes da Consagração ${ }^{15}$. Seu texto é o seguinte:

\begin{tabular}{|l|l|}
\hline Sanctus, Sanctus, Sanctus, & Santo, Santo, Santo, \\
Dominus Deus Sabaoth. & É o Senhor Deus das milícias celestes. \\
Pleni sunt cæli et terra gloria tua. & Cheios estão céu e terra da vossa glória. \\
Hosanna in excelsis. & Hosana nas alturas. \\
& \\
Benedictus qui venit in nomine Domini. & Bendito o que vem em nome do Senhor. \\
Hosanna in excelsis. & Hosana nas alturas ${ }^{16}$. \\
\hline
\end{tabular}

Tabela 2 - O Sanctus da Missa

Quanto à composição do texto, o Sanctus é formado de duas partes:

a) Do princípio até o Benedictus, é tomado do Antigo Testamento, do livro do profeta Isaías (VI, 1-3), que viu o Senhor sentado em um trono elevado, com Serafins que o cercavam e adejavam clamando uns aos outros: "Santo, Santo, Santo [...]".

b) O Benedictus é tomado do Novo Testamento e é o mesmo clamor de júbilo com que o povo ovacionava a entrada de Jesus Cristo em Jerusalém: " $\mathrm{E}$ toda aquela multidão, que o precedia e que o seguia, clamava: Hosana ao filho de Davi! Bendito seja aquele que vem em nome do Senhor! Hosana no mais alto dos céus!" (Evangelho de Mateus, XXI, 9).

Estas duas partes do Sanctus são assim explicadas por Santo Tomás de Aquino: "Acabado o prefácio, o povo louva devotamente a divindade de Cristo,

\footnotetext{
${ }^{14}$ Considerada enquanto composição litúrgica, a Missa no Rito Romanoé integrada por uma série de trechos, divididos em duas categorias: o Próprio (partes variáveis conforme a festividade litúrgica) e o Ordinário (partes cantadas em quase todas as Missas). São justamente as cinco peças do Ordinário (Kyrie, Gloria, Credo, Sanctus-Benedictus e Agnus Dei) que configuram a forma musical comumente denominada "Missa" (Bas, 1947, p. 139-140).

15 Sobre a relação do momento da Consagração e o Sanctus: "Esta parte [a Consagração] é preparada pelo Prefácio, solene oração de louvor e agradecimento. Como introdução, o sacerdote diz: "Sursum corda!" (Elevai os corações!) Por fim, une-se aos coros dos Anjos, dizendo: Santo, Santo, Santo etc. As orações, depois do Sanctus, são ditas em voz baixa, daí o nome de Missa Secreta. Dá-se o nome de Cânon à parte da santa Missa que vai do Sanctus atéo Pater Noster porque estas orações não variam (Boulenger, 1949, p. 285). Em uma Missa cantada, o Coro canta o Sanctus justamente durante o tempo em que o sacerdote pronuncia as orações entre o fim do Prefácio e a Consagração propriamente dita.

${ }^{16}$ Tradução de Lefebvre, 1956.
} 
dizendo com os anjos: Santo, Santo, Santo. E a humanidade de Cristo, com os meninos: Bendito o que vem" (Summa theologiae, III parte, questão 83, artigo $4^{17}$ ).

A tradição de música sacra polifônica no estilo de Palestrina - elogiado por São Pio X no Motu proprio - trata todas as partes do Ordinário da Missa como uma elaboração de uma base temática pressuposta (uma melodia gregoriana, uma canção etc.), sob a forma de motetos $^{18}$. No caso do Sanctus, a constituição do seu texto já claramente impõe a forma de Responsório, ou seja, o modelo $a-b-a^{\prime}$ : após uma primeira parte (chamada corpo do responsório), sucede outra (o versículo) e, em seguida, retorna-se à primeira parte, que não é repetida inteiramente, sendo executada somente sua última frase (a frase de repetição) (Bas, 1947, p. 129-133). O corpo é o trecho "Sanctus, Sanctus, Sanctus etc."; a frase de repetição é o "Hosana in excelsis"; e o versículo é o "Benedictus etc". Tradicionalmente, as composições polifônicas no estilo palestriniano exploravam esta forma de responsório do Sanctus por meio de uma articulação de texturas corais, frequentemente alterando o número de vozes ao longo das seções, cada qual sendo estruturada como um moteto. Eis um exemplo:

\begin{tabular}{|c|c|c|c|c|}
\hline Coro a 4 vozes & Coro a 3 vozes & Coro a 4 vozes & $\mathbf{3}$ ou 4 Solos & Coro a 4 vozes \\
\hline Sanctus & Pleni sunt cæli & Hosanna & Benedictus & Hosanna \\
\hline
\end{tabular}

Tabela 3 - Mudanças de textura no Sanctus polifônico (Bas, 1947, p. 147)

Inicialmente, nos primeiros séculos da história da Igreja, o Sanctus era cantado pelos fiéis, daí porque algumas melodias gregorianas antigas serem bastante simples (Reus, 1944, p. 247). Com o tempo, os cantos do Sanctus passam a ser mais ornados, mais longos, resultando no costume de que sua execução seja dividida em duas partes ${ }^{19}$. Quando se trata, pois, de um Sanctus polifônico, em razão da extensão do canto completo, o Coro geralmente canta o Sanctus até o

\footnotetext{
17 Tomás de Aquino, 2001.

18 “Um importante gênero musical desde o século XIII ao XVIII; e de menor importância a partir de então. Em razão de que definição alguma pode englobar as características do moteto duranteo inteiro curso de seu desenvolvimento, é conveniente distinguir três fases principais. Na primeira (1200-1450), o termo moteto denota uma estrutura específica: um tenor derivado do cantochão serve como fundamento para novas vozes superiores; a composição resultante é heterogênea tanto no estilo musical das vozes individuais como em seus textos. Na segunda fase (1450-1600), moteto denota um gênero: composição polifônica de um texto sacro em Latim. Na terceira fase (após 1600), o termo, ainda que retendo seu significado básico como um tipo de música sacra, tornou-se associado a um estilo particular (stills motecticus): o estilo sério e imitativo da polifonia eclesiástica derivada de Palestrina" (Randel, 2003, p. 529).

${ }^{19}$ Mesmo com a maior complexidade dos cantos, parece que mesmo na época carolíngia o canto do Sanctus por todos os fiéis era especialmente desejado: “Em 789, um decreto de Carlos Magno determina que o Sanctus seja cantado tanto pelos celebrantes quanto pela assembleia. Por que esse canto e não outro? Porque é o mais solene e sagrado dos cantos da missa" (Viret, 2015, p. 42).
} 
primeiro Hosanna in excelsis e executa o Benedictus com o segundo Hosanna apenas após a Consagração, para, assim, melhor glorificar a vinda de Jesus Cristo ao altar (Boulenger, 1949, p. 331). Daí, pois, certa independência de caráter musical que o Benedictus pode assumir em relação ao Sanctus. No presente artigo daremos especial atenção à primeira destas duas partes, ou seja, ao Sanctus.

\section{4 - A Missa Te Deum laudamus de Perosi}

Entre as muitas obras compostas por Lorenzo Perosi ${ }^{20}$, apenas algumas de suas Missas foram publicadas e amplamente divulgadas ${ }^{21}$. Em tais Missas, evidencia-se uma grande variedade na formação coral explorada pelo compositor. Sua famosa Missa Pontificalis, por exemplo, é feita para três vozes mistas e coro, enquanto seu Requiem é para três vozes masculinas e sua Missa Eucharistica é para quatro vozes mistas. Chamou-nos a atenção, por sua vez, a Missa Te Deum laudamus, publicada pela Ricordi italiana em 1899, na qual Perosi se vale de uma formação semelhante àquela utilizada por Nepomuceno em sua Missa, a saber, duas vozes e órgão: tenor e baixo na Missa de Perosi e duas vozes femininas na de Nepomuceno. Um segundo aspecto digno de nota é o fato de que tal Missa foi executada no Rio de Janeiro já pouco tempo após sua edição italiana, fato evidenciado por periódicos cariocas nos primeiros anos do século XX.

Na edição de 31 de Agosto de 1904 do Jornal do Brasil, por exemplo, lê-se uma série de notícias sobre um importante evento para os católicos brasileiros. Tratava-se de uma grande peregrinação ao Santuário de Aparecida, no interior do Estado de São Paulo, promovida para comemorar o quinquagésimo aniversário da definição do dogma da Imaculada Conceição de Nossa Senhora. Fizeram-se presentes em Aparecida diversos Bispos de todo o Brasil, merecendo destaque a participação do Cardeal Dom Joaquim Arcoverde de Albuquerque Cavalcanti, Arcebispo do Rio de Janeiro, a quem coube a celebração da Missa Pontifical no dia 8 de Setembro, data destinada às cerimônias de solene Coroação de Nossa Senhora. O Jornal do Brasil dava ainda detalhes sobre a parte musical da festa religiosa, indicando que "todo o serviço musical, durante a festa, será feito

\footnotetext{
${ }^{20}$ Possivelmente três a quatro mil obras no total (Ciampa, 2006, p. xxxiii).

21 “Eis a lista completa das obras de Perosi que foram impressas no catálogo da Casa Ricordi (até 2005): La Passione di Cristo Secondo San Marco, La Risurrezione di Cristo, Missa Cerviana, Missa da Requiem a 3 voci machili, Missa 'Benedicamus Domino', Missa Eucharistica, Missa Pontificalis, Missa Secunda Pontificalis, Missa 'Te Deum laudamus'. E é isto. Dois oratórios e sete Missas. Menos que 4,5 horas de música. [...] Evidentemente há outras editoras, sobretudo a Armelin (Pádua), que publicaram suas obras menores. Mas sendo a Casa Ricordi a soberana das casas editoriais da Itália, a brevidade da lista é ultrajante" (Ciampa, 2006, p. 322; 353).
} 
pelos alunos e professores dos colégios dos revs. padres Salesianos de Lorena e Guaratinguetá". Em seguida, apresentava-se o programa musical para as cerimônias, desde o dia $1^{\underline{0}}$ de Setembro até o dia 7 (Setenário preparatório para a festa do dia 8). Destacamos o programa musical previsto para o dia 8: “De manhã: Ecce sacerdos, de M. Perosi. Missa (Te Deum Laudamus) de Perosi. Ao Offertorio (Exaudi Domine) M. Perosi. Regina coeli (coral). Te-Deum (coral). Jesu Corona Virginum (M. Devolle)" (grifo nosso).

Além disso, em, no mínimo, duas outras ocasiões registradas em periódicos cariocas, vemos a mesma Missa Te Deum Laudamus de Perosi sendo executada no Rio de Janeiro. Na Gazeta de Notícias, em sua edição de 13 de Junho de 1909, noticiava-se que no próprio dia 13, por ocasião da festa de Santo Antônio, "será executada a missa (Te Deum Laudamus), do padre Perosi" por distintas amadoras. O jornal O Paiz, em sua edição de $1^{\circ}$ de Novembro de 1914, noticia o encerramento do mês do Rosário com Missa na matriz de Santa Rita, sendo "executada pelo coro da matriz a missa Te Deum laudamus, do maestro sacro monsenhor Perosi, orquestrada pelo maestro brasileiro Arnaud Gouveia, que tocará o harmonium". Merece destaque também o fato de que Arnaud Duarte Gouveia (1865-1942) foi discípulo de Alberto Nepomuceno e consta como um dos organistas atuantes no Rio de Janeiro, na Igreja da Cruz dos Militares ${ }^{22}$.

Assim, pois, sabemos que na primeira década do século $\mathrm{XX}$ a Missa Te Deum laudamus de Perosi já era conhecida e executada em cerimônias católicas no Brasil. A relevância de tal fato ao presente estudo é que a estrutura do Sanctus desta Missa é praticamente idêntica ao Sanctus de Nepomuceno, o que nos parece sugerir uma provável influência do maestro italiano sobre o compositor brasileiro.

\section{5 - Análise Comparativa}

Quanto à estrutura geral, no que concerne à divisão dos diversos períodos do texto litúrgico entre as vozes e à respectiva textura coral empregada, o Sanctus da Missa de Nepomuceno e o Sanctus da Missa Te Deum laudamus de Perosi podem ser considerados idênticos. Ambos se valem da forma de Responsório e fundamentam a distinção das partes na maior ou menor orquestração vocal e no emprego de texturas homofônicas e imitativas:

${ }^{22}$ Schubert, 1980. p.34-37. 


\begin{tabular}{ll}
\hline & SANCTUS \\
\hline Introdução & Órgão Solo \\
\hline Sanctus, Sanctus, & Voz 1 Solo \\
\hline Sanctus, Dominus Deus Sabaoth. & Voz 2 Solo \\
\hline Pleni sunt cæli et terra & Voz 1 e $2-$ Textura homofônica \\
& \\
\hline gloria tua. & Voz 1 e 2 - Textura imitativa \\
\hline Hosanna in excelsis. & Voz 1 e 2 - Textura homofônica \\
\hline & BENEDICTUS \\
\hline Introdução & Órgão Solo \\
\hline Benedictus qui venit in nomine Domini. & Voz 1 Solo \\
& Voz 2 Solo \\
\hline Hosanna in excelsis. & Voz 1 e 2 - Textura homofônica \\
\hline
\end{tabular}

Tabela 4 - Forma geral do Sanctus e Benedictus de Nepomuceno

\begin{tabular}{lc}
\hline & \multicolumn{2}{c}{ SANCTUS } \\
\hline Introdução & Órgão Solo \\
\hline Sanctus, Sanctus, & Voz 1 Solo \\
\hline Sanctus, Dominus Deus Sabaoth. & Voz 2 Solo \\
\hline Pleni sunt cæli et terra & Voz 1 e 2 - Textura homofônica \\
& \\
\hline gloria tua. & Voz 1 e 2 - Textura imitativa \\
\hline Hosanna in excelsis. & Voz 1 e 2 - Textura homofônica \\
\hline Introdução & BENEDICTUS \\
\hline Benedictus qui venit in nomine Domini. & Órgão Solo \\
\hline Hosanna in excelsis. & Voz 1 Solo \\
\hline
\end{tabular}

Tabela 5 - Forma geral do Sanctus e do Benedictus da Missa Te Deum laudamus de Perosi

Quanto à extensão das diferentes partes, há também uma grande semelhança entre as duas peças:

\begin{tabular}{|c|c|l|c|c|}
\hline \multicolumn{2}{|c|}{} & Perosi & Nepomuceno \\
\hline \multirow{2}{*}{ Parte 1 } & A & Sanctus, Sanctus, Sanctus, & 3 compassos & 5 compassos \\
\cline { 2 - 5 } & B & Dominus Deus Sabaoth. & 4 compassos & 3 compassos \\
\hline \multirow{3}{*}{ Parte 2 } & C & Pleni sunt cæli et terra & 3 compassos & 5 compassos \\
\cline { 2 - 5 } & D & gloria tua. & 3 compassos & 3 compassos \\
\cline { 2 - 5 } & E & Hosanna in excelsis. & 6 compassos & 7 compassos \\
\hline \multicolumn{2}{|r|}{ Total: } & 22 compassos & 28 compassos \\
\hline
\end{tabular}

Tabela 6 - comparação entre os Sanctus de Nepomuceno e Perosi quanto à extensão das partes 
No Sanctus de Perosi, há três compassos de Introdução com solo de órgão. Trata-se de um trecho com escrita polifônica a 4 vozes, com clara independência das vozes e, ao mesmo tempo, uma estrutura cadencial tonal tradicional ( $\mathrm{Si}$ menor: i-V7/III) preparando a entrada da linha vocal no acorde da relativa maior (Ré Maior) (ver Figura 1). A escrita contrapontística evidencia-se também pelo fato de que o "tema" da Missa, indicado pelo próprio compositor no início do Kyrie - primeira peça da Missa, aqui aparece na voz de contralto, ou seja, como parte integrante de um conjunto mais amplo e não como voz principal, tal como ocorre nas outras peças da Missa (ver Figura 2).

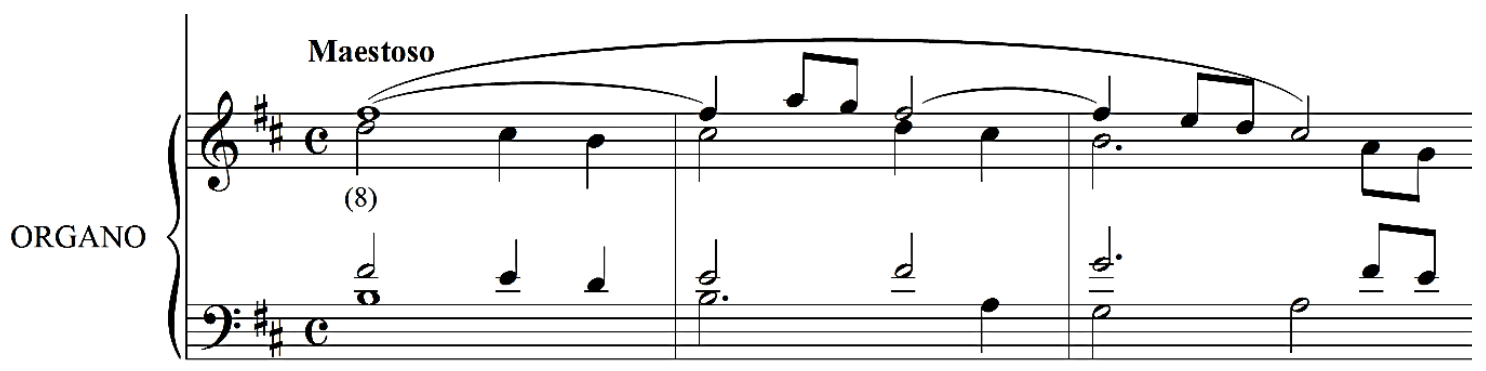

Figura 1 - Sanctus da Missa Te Deum laudamus de L. Perosi, compassos 1 a 3.

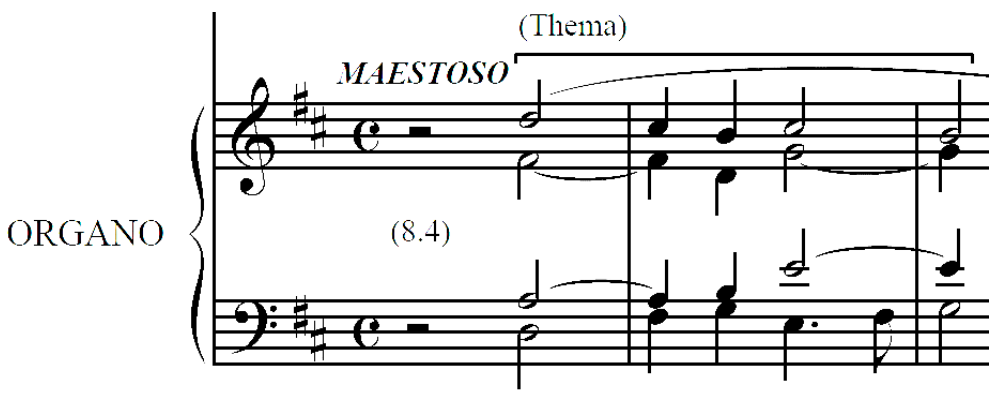

Figura 2 - Tema da Missa Te Deum laudamus de L. Perosi, início do Kyrie.

Na Introdução do Sanctus da Missa de Nepomuceno, encontramos procedimento compositivo semelhante. Trata-se também de um trecho com escrita contrapontística, em que se evidencia a proposta de independência das vozes, ainda que em grau inferior a Perosi. Nepomuceno vale-se de grande variedade de acordes juntamente com uma mobilidade melódica do baixo e com o uso constante de terças paralelas, enfraquecendo o caráter estritamente contrapontístico. Considerando o fato de que a entrada do canto no compasso 6 se dá no acorde da Tônica (Ré Maior), não há muita dificulda de em se reconhecer em tal trecho introdutório uma cadência típica (Ré Maior: I-IV-I6-V4/3-I) como um grande prolongamento da Tônica inicial23 (ver Figura 3). Assim como ocorre

23 “As raízes do acorde prolongado se encontram no contraponto puro. Está baseado sobre o princípio manifestado pelo contraponto de que várias notas podem representar a uma nota que domina sobre o grupo delas. [...] A partir deste conceito melódico-contrapontístico 
na Missa Te Deum laudamus de Perosi, também Nepomuceno elabora um tema solo do órgão que se repete no início de todas as peças da Missa (Kyrie, Gloria, Credo e Agnus Dei), com exceção, justamente, do Sanctus-Benedictus (ver Figura 4).

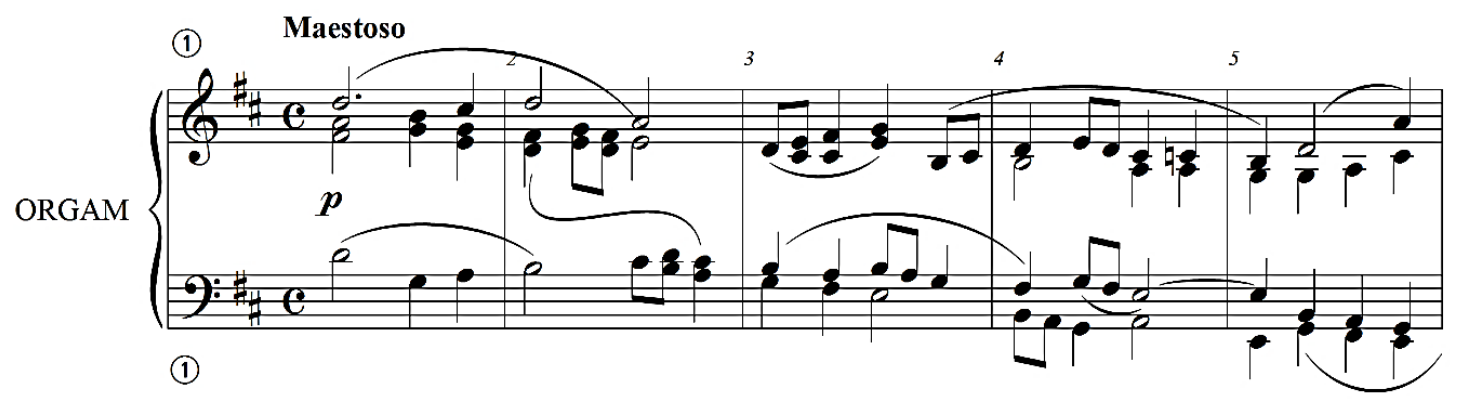

Figura 3 - Sanctus da Missa de A. Nepomuceno, compassos 1 a 5

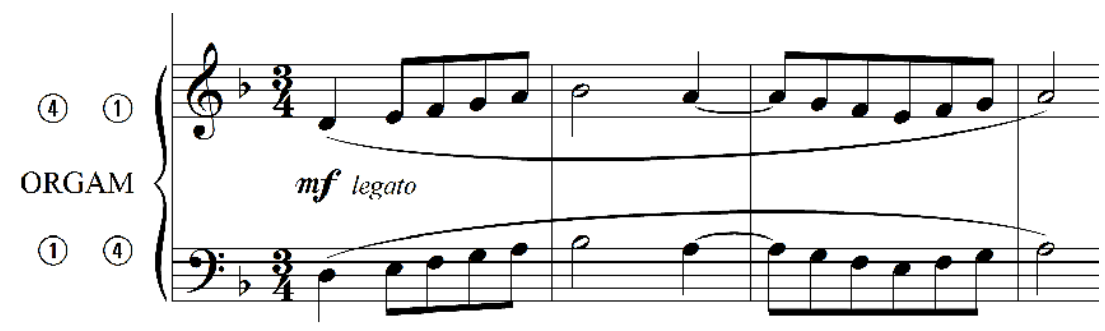

Figura 4 - Introdução da Missa de A. Nepomuceno, início do Kyrie

No Sanctus de Perosi, nos compassos 4 e 5, encontramos a primeira declamação do texto: o tenor canta Sanctus, Sanctus. Trata-se de dois incisos ${ }^{24}$ : uma quarta descendente (mínima pontuada e semínima) e duas notas iguais (duas mínimas). Harmonicamente, o primeiro inciso elabora uma dominante secundária que conduz ao VI grau no segundo inciso (Ré Maior: V7/VI). Seguese, em seguida, um compasso com solo de órgão que se inicia com o acorde de Subdominante e por meio de uma bordadura introduz a segunda declamação do texto, a saber, o baixo cantando Sanctus, Dominus Deus Sabaoth. Perosi usa, então, uma estrutura análoga à primeira: dois incisos idênticos aos compassos 3 e 4

provavelmente se chegou ao reconhecimento de que o valor estrutural de um acorde pode ser prolongado com a ajuda de vários acordes" (Salzer, 1995, p. 123).

${ }^{24}$ Não há consenso entre os tratadistas quanto à denominação da célula básica da frase musical e nem mesmo quanto aos maiores agrupamentos musicais. Zamacois (1960, p. 9-10), por exemplo, chama as menores unidades de membros de subperíodo. Sobre o período musical, diz Ratner (2001) que tem havido "considerável desacordo quanto aos termos utilizados para se discutir a estrutura do período, e mesmo quanto à natureza exata do período em si". Para o presente artigo, nos limitaremos a utilizar o termo inciso como unidade musical básica, limitada ao âmbito de um compasso, e para as estruturas que surgem a partir dele faremos uso dos termos sub-frase (dois ou três compassos, ordinariamente) e frase (quatro ou seis compassos, ordinariamente) (Bas, 1947). 
(salto descendente de $4^{a}$ seguido por notas iguais), com configuração harmônica também baseada no uso de dominante secundária (V/iv-iv), seguidos por dois incisos nas palavras Deus (duas semínimas configurando uma segunda menor descendente) e Sabaoth (uma terça maior ascendente preenchida com grau conjunto). Harmonicamente tem-se em Deus o encadeamento vii ${ }^{\circ} 4 / 3-16$ e em Sabaoth, a sequência VI-(IV6)-V (cadência frígia ${ }^{25}$ ). Em suma, trata-se de uma frase de 7 compassos, sendo um compasso preenchido com solo de órgão, no formato ternário A-A'-B, ou seja, constituída por duas semi-frases binárias semelhantes (A-A') em (i) Sanctus, Sanctus e (ii) Sanctus, Dominus, seguidas por uma semi-frase contrastante (B) em Deus Sabaoth. Harmonicamente, tem-se um claro encaminhamento da Tônica (Si menor), apresentada na Introdução, para a Dominante (ver Figura 5).

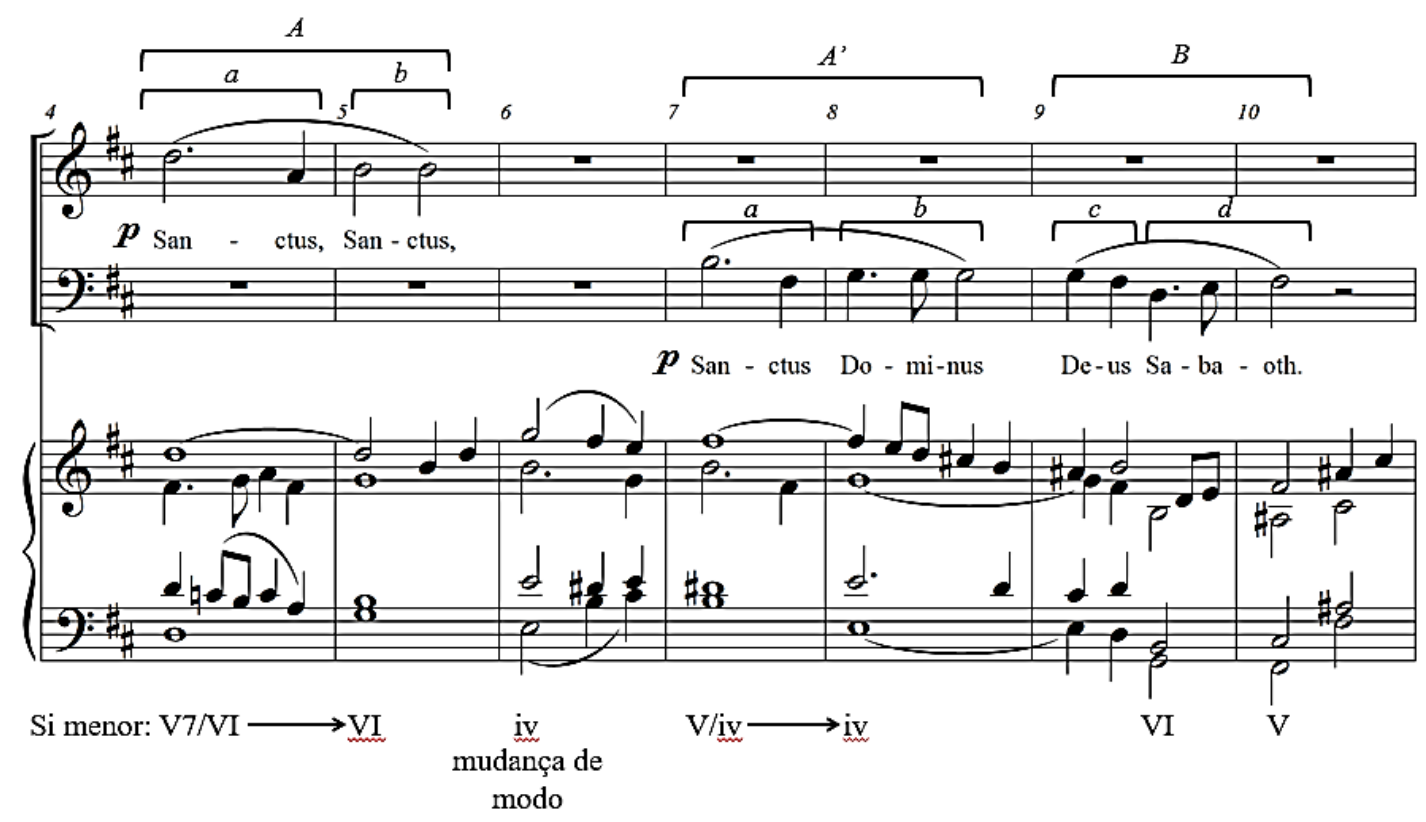

Figura 5 - Sanctus da Missa Te Deum laudamus de L. Perosi, compassos 4 a 10

No Sanctus de Nepomuceno, encontramos uma estruturação formal muito semelhante. Nos compassos 6 e 7, encontramos a primeira declamação do Canto: o primeiro soprano cantando Sanctus, Sanctus, em uma semi-frase binária constituída por dois incisos quase idênticos. Harmonicamente, tem-se o primeiro inciso na Tônica e o segundo, na Dominante, com finalização na sua relativa menor (iii grau). Em seguida, tem-se um compasso com solo de órgão conduzindo a harmonia para o ii grau. Tal como na obra de Perosi, também

25 "A cadência frígia é um maneirismo barroco que consiste em uma cadência final IV6-V no modo menor ao final de um movimento lento ou de uma introduçãolenta. Indica a continuação imediata de um movimento rápido, geralmente na mesma tonalidade. A cadência frígia recebeu este nome, não com muito acerto, devido ao movimento de semitom no baixo, que se supõe ser uma sobrevivência da cadência II-I do século XV" (Piston, 1998, p. 177). 
Nepomuceno vale-se de uma semi-frase binária em modo maior sucedida por solo de órgão em modo menor que funciona como uma ponte para a segunda declamação do texto. Entre os compassos 9 a 13, Nepomuceno estrutura a segunda parte do texto (Sanctus, Dominus Deus Sabaoth) de modo análogo a Perosi. O primeiro inciso (texto Sanctus) é praticamente idêntico ao do compositor italiano: uma terça descendente em mínima pontuada seguida de semínima, enquanto o de Perosi é uma quarta descendente. O segundo inciso é idêntico: três notas repetidas na figuração rítmica semínima pontuada-colcheiamínima. Na semi-frase seguinte, Nepomuceno utiliza também dois incisos contrastantes entre si. O movimento melódico geral desta semi-frase é quase uma inversão perfeita do trecho que lhe corresponde no Sanctus de Perosi. Em Deus, Perosi faz uma segunda menor descendente sucedida por um salto de terça maior também descendente; enquanto Nepomuceno faz a mesma sequência, mas na direção ascendente. Em Sabaoth, Perosi faz um contorno ascendente por grau conjunto no âmbito de uma terça; enquanto Nepomuceno o faz em um contorno descendente no âmbito de uma quarta justa. Harmonicamente, também Nepomuceno conduz este trecho inicial da Tônica (na Introdução e na primeira declamação) à Dominante, no compasso 13. Entretanto, enquanto Perosi se vale de uma sequência de dominantes secundárias em seu processo de encadeamento rumo à Dominante, Nepomuceno opta por um procedimento diferente, basicamente concatenando diferentes acordes diatônicos, mas inserindo, no compasso 11, um colorido tonal específico: o acorde de Dó Maior, Subdominante da Subdominante da tonalidade principal (ver Figura 6).

Digno de nota é outro traço de semelhança entre estes trechos iniciais dos dois Sanctus: a dinâmica piano desde a Introdução até o acorde de Dominante.

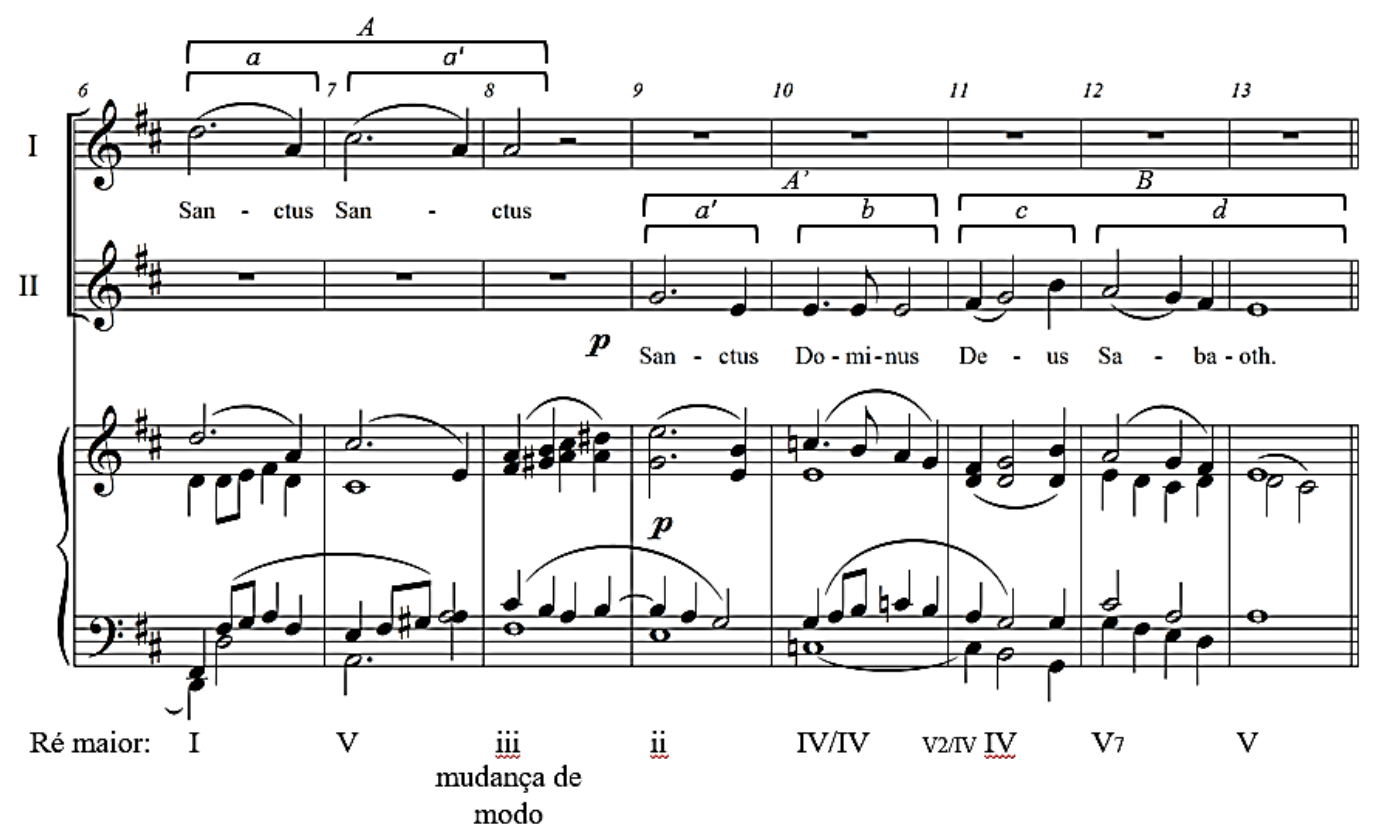

Figura 6 - Sanctus da Missa de A. Nepomuceno, compassos 4 a 13. 
No Pleni sunt caeli et terra, nos compassos 11 a 13, Perosi coloca as indicações de tutti eforte, evidenciando uma mudança de caráter dentro da peça. Órgão, tenor e baixo realizam tal trecho em perfeita conformidade rítmica. As duas vozes cantam em uníssono, enquanto que o órgão, em textura contrapontística a quatro vozes, expõe na voz superior o tema da Missa (ver Figura 2). A linha melódica do Canto consiste basicamente em uma ascensão no âmbito de uma quinta (Fá\#-Dó\#), seguida por uma linha descendente em graus conjuntos no âmbito de uma sexta maior (Dó\#-Mi). Harmonicamente, tem-se encadeamento semelhante ao da Introdução: i (prolongado por acordes de passagem)-v-VI-V/III. Tal trecho apresenta, analogamente ao trecho introdutório, uma condução harmônica que prepara o trecho seguinte na relativa maior, novamente com uso da dominante secundária (ver Figura 7).

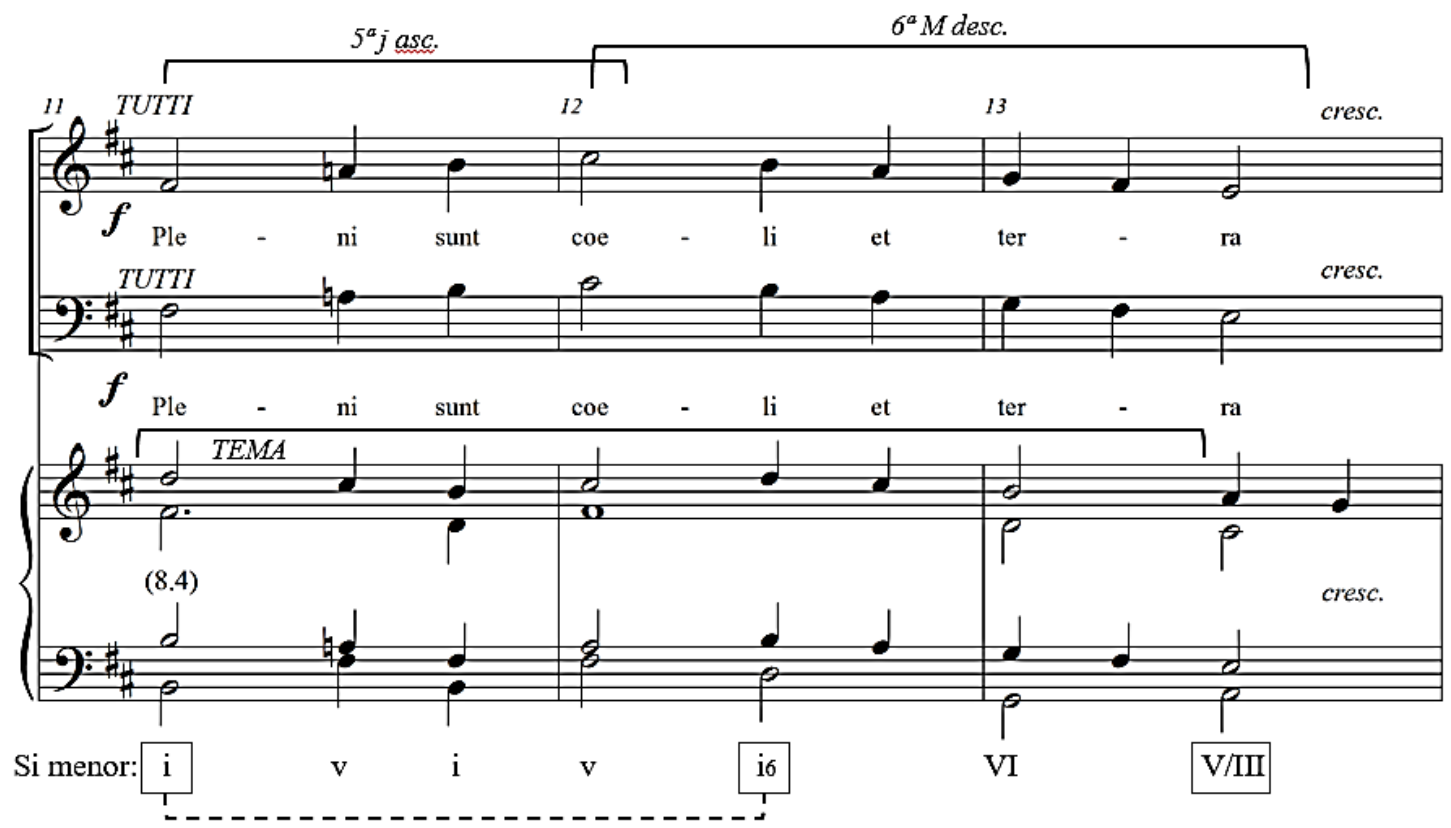

Figura 7 - Sanctus da Missa Te Deum laudamus de L. Perosi, compassos 11 a 13

Nepomuceno também elabora o seu Pleni sunt caeli et terra com procedimentos compositivos quase idênticos aos do Sanctus de Perosi. Em primeiro lugar, a indicação de dinâmica forte. Em segundo lugar, a perfeita homofonia entre as duas vozes e o órgão, ainda que com a diferença de que as vozes não estão em uníssono. Os valores rítmicos são quase os mesmos de Perosi, com o predomínio do uso da unidade de tempo, a semínima. O perfil melódico da voz superior é bastante próximo ao do italiano: uma subida melódica dentro do âmbito de uma quinta justa (Ple ... ni sunt caeli) seguida por uma descida por grau conjunto no âmbito de uma sexta maior (Fá\#-Lá com uma bordadura inferior Lá-Sol\#-Lá). Harmonicamente, tem-se uma movimentação da Tônica (prolongada por acordes de passagem) à Dominante, processo este equivalente 
ao utilizado por Perosi em tonalidade menor, a saber, movimento da Tônica menor à relativa maior. Deparamo-nos, porém, com uma diferença interessante na declamação do texto. Perosi coloca como nota culminante do perfil melódico e como nota mais longa (uma mínima) o acento tônico de CCE-li, Nepomuceno o faz com a sílaba fraca da mesma palavra, co-LI. Além disso, enquanto Perosi vale-se de um estilo estritamente silábico, Nepomuceno dispõe algumas sílabas em mais de uma nota do contorno melódico, resultando numa maior amplitude da linha (ver Figura 8).

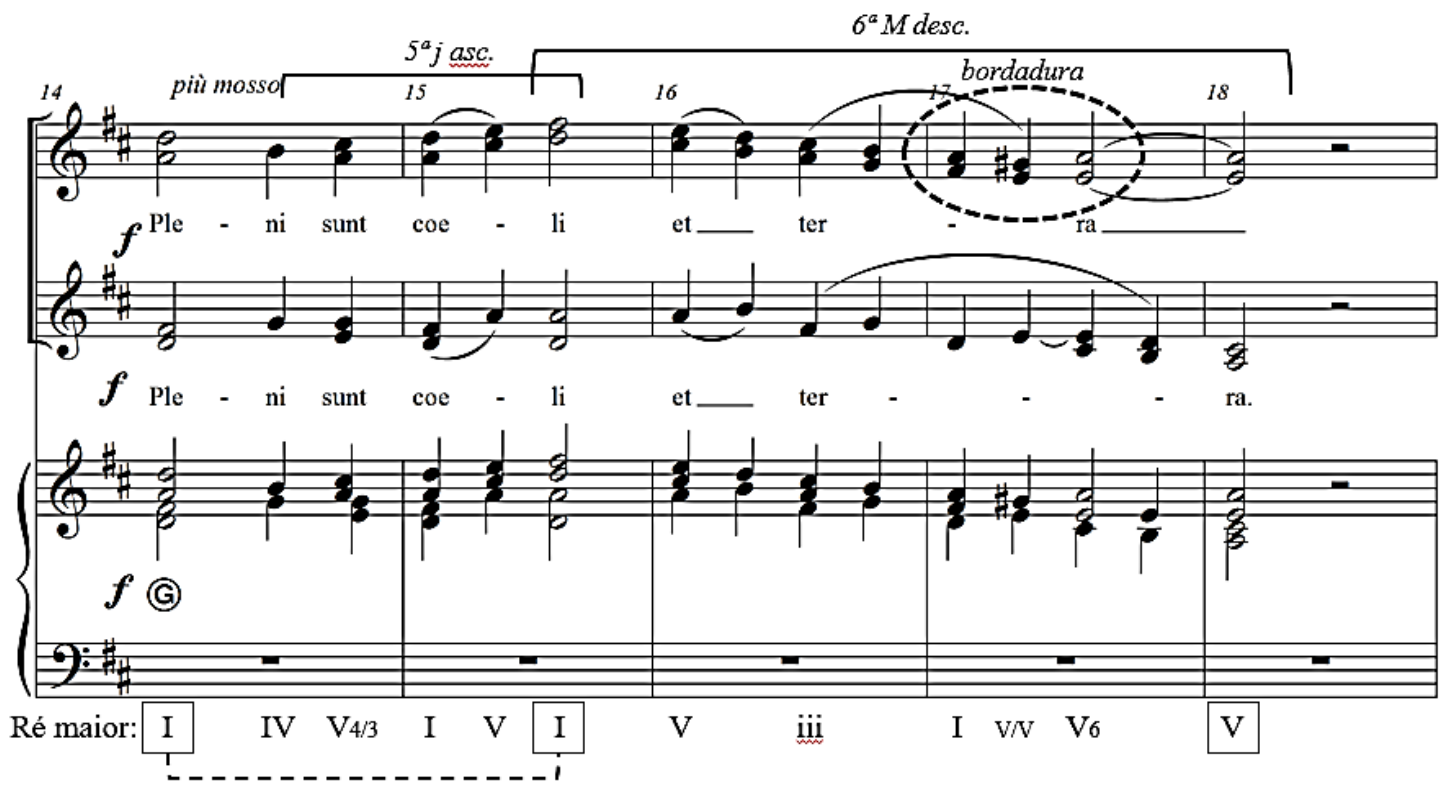

Figura 8 - Sanctus da Missa de A. Nepomuceno, compassos 14 a 18

O trecho seguinte de ambos os Sanctus, a saber, o gloria tua, dura apenas três compassos, mas é de tal forma peculiar em sua construção e o processo usados pelos dois compositores é tão semelhante, que a influência direta de uma obra sobre a outra extrapola o grau de mera possibilidade hipotética.

Em Perosi, o gloria tua é cantado duas vezes por ambas as vozes de maneira alternada em um movimento de sequência melódica ascendente, com uma estrutura formal de uma frase constituída por quatro incisos muito semelhantes (arpejo ascendente seguido por grau conjunto dentro do âmbito de uma sexta maior) e num movimento harmônico amplo de prolongamento do acorde de relativa maior: III (VI-iv-V/III) - III. Trata-se, pois, de um breve trecho em que o caráter imitativo empregado na textura das vozes é usado como meio de variedade harmônica e incremento de tensão como preparação ao trecho final - Hosanna in excelsis (ver Figura 9). 


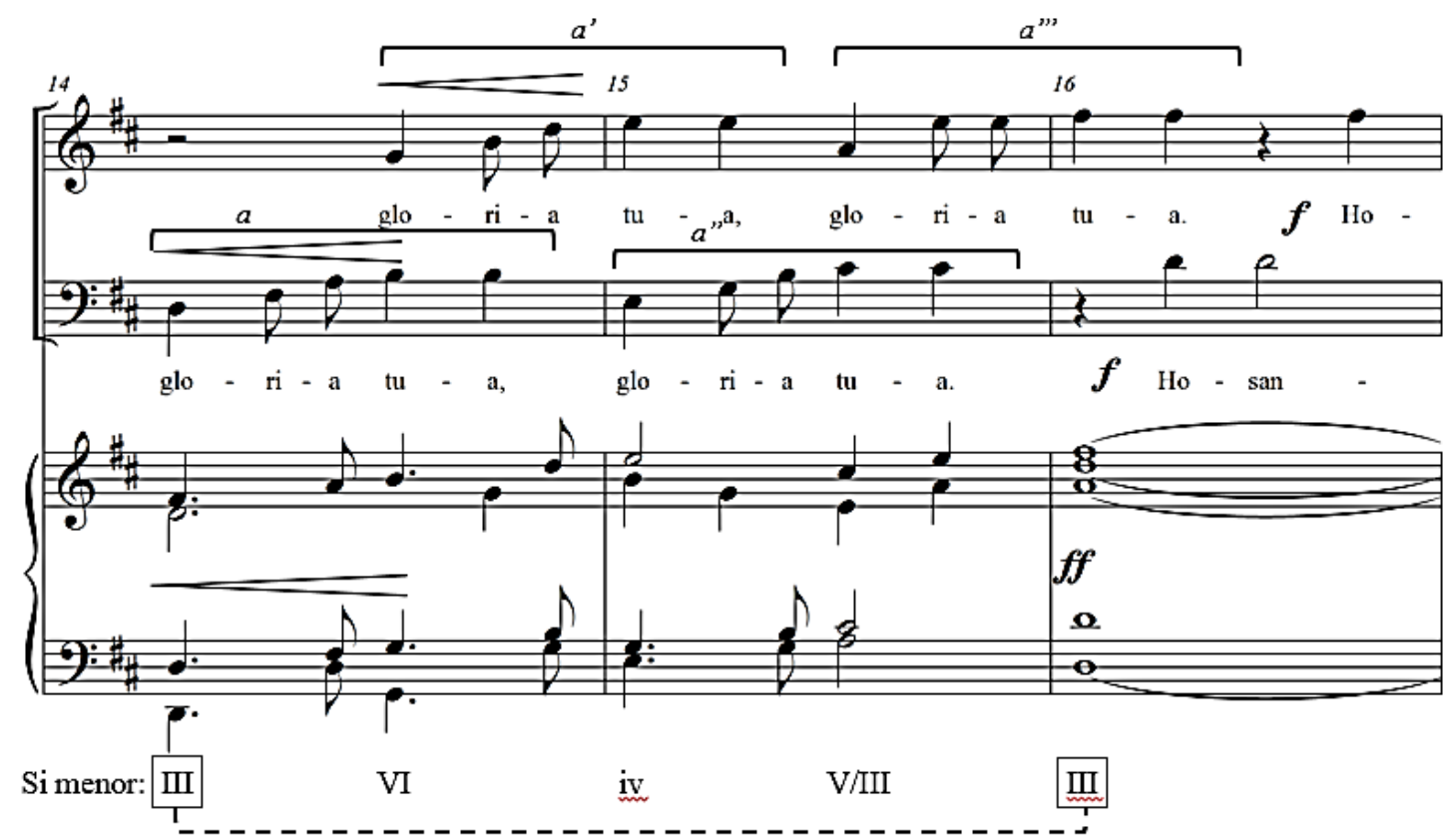

Figura 9 - Sanctus da Missa Te Deum laudamus de L. Perosi, compassos 14 a 16

Em Nepomuceno, a descrição anterior aplica-se perfeitamente, com exceção do perfil melódico que caracteriza os incisos (graus conjuntos ascendentes dentro do âmbito de uma $4^{\mathrm{a}}$ justa) e do fato de que o prolongamento harmônico não se refere ao III grau, mas ao IV grau: IV-ii-IV/IV-V/IV-IV (ver Figura 10).

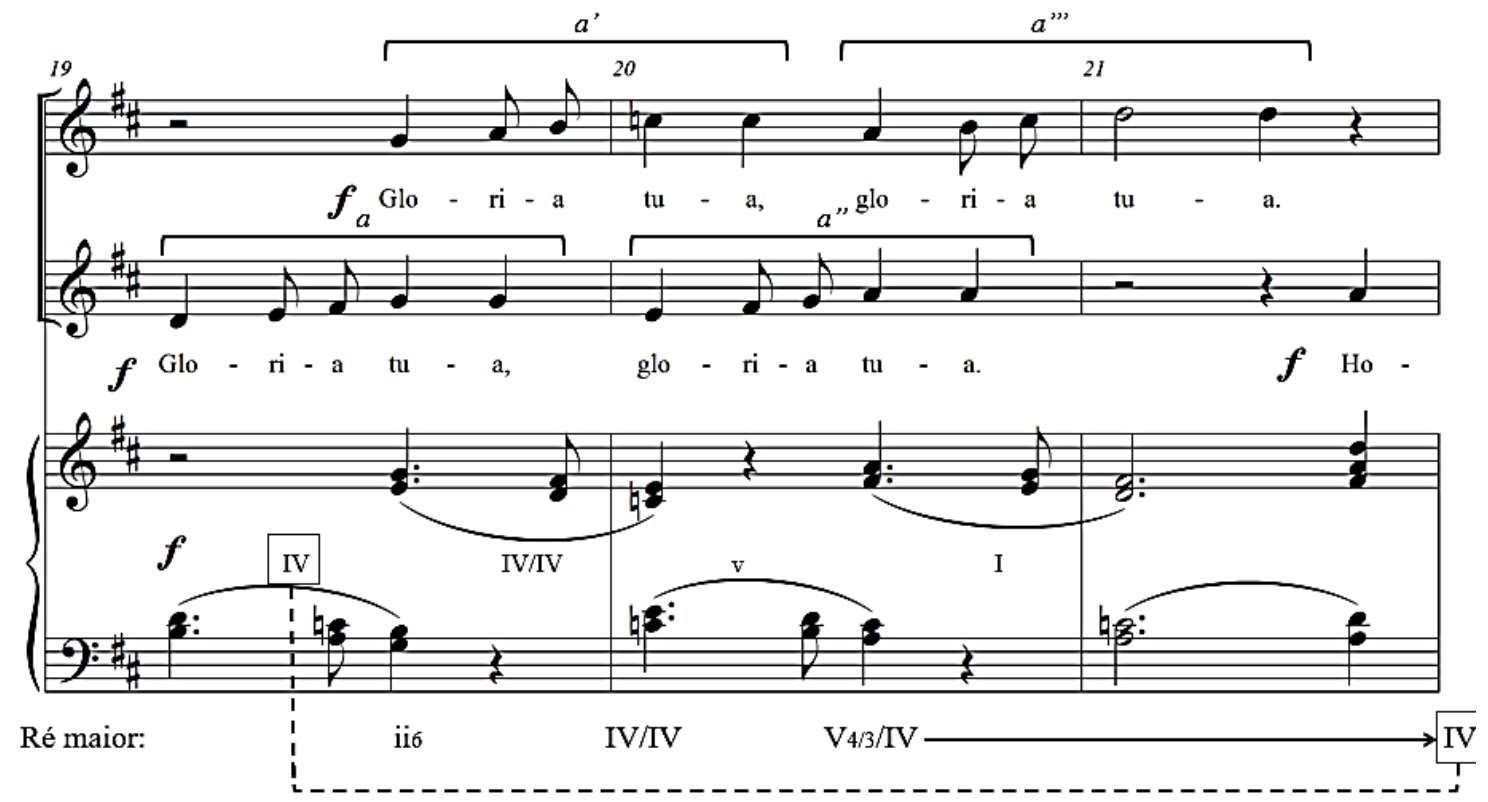

Figura 10 - Sanctus da Missa de A. Nepomuceno, compassos 19 a 21

Finalmente, tem-se o Hosanna in excelsis. No Sanctus de Perosi é um trecho de 6 compassos, com uma dupla declamação do texto em uma frase de 3 
compassos (incompletos) e outra de 4 compassos. A primeira frase, com contorno melódico em graus conjuntos descendentes, é iniciada por uma alternância de entrada das vozes seguida por textura homofônica. Harmonicamente, tem-se um prolongamento do acorde da relativa maior e a preparação à Subdominante menor, por meio de sua respectiva dominante secundária (V/iv). Em seguida, tem-se a mesma sequência descendente de graus conjuntos e inteiramente homofônica, iniciando-se, assim, a cadência autêntica perfeita final (iv-V-I) com terça de picardia no último acorde e nota pedal sobre a Dominante na linha do órgão. Além disso, no antepenúltimo e no penúltimo compasso há um tratamento de dissonância característico do contraponto palestriniano tradicional: suspensão na voz do baixo resolvida em consonância imperfeita (3 $3^{\text {a }}$ maior) ornamentada com bordadura inferior (ver Figura 11).

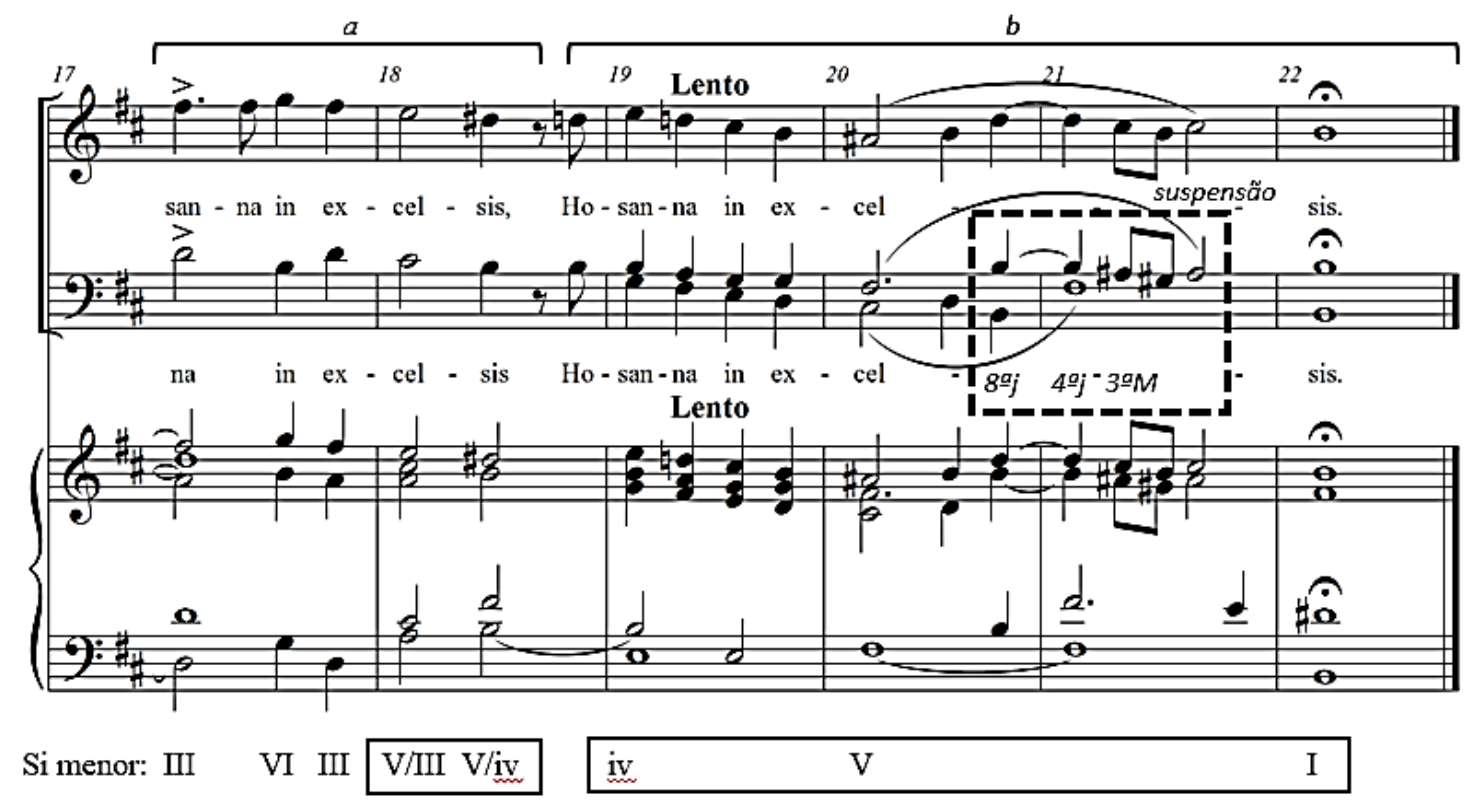

Figura 11 - Sanctus da Missa Te Deum laudamus de L. Perosi, compassos 17 a 22 (final)

Em Nepomuceno, encontramos um trecho de 7 compassos, dividido em duas frases, uma de 3 e outra de 4 compassos, nas quais se cantam também duas vezes o texto Hosanna in excelsis. Não apenas a extensão da frase e a repetição da declamação do texto são quase idênticas às de Perosi, como também o é a utilização da mudança de modo e da tensão provocada pelo acorde de Dominante. Com efeito, Nepomuceno inicia o trecho com o acorde de Subdominante e a conduz ao acorde de sétima da Dominante. Em seguida, não se alcança a esperada Tônica, mas a relativa menor, o vi grau, configurando, assim, uma espécie de cadência de engano e postergando o fechamento da peça para os compassos seguintes, nos quais novamente centraliza-se o enfoque harmônico sobre o acorde de Subdominante, por meio dos acordes IV/IV e V/IV nos compassos 25-26 e, sobretudo, pela cadência plagal nos dois compassos 
finais. Digno de nota também o fato de que Nepomuceno utiliza nestes compassos o mesmo procedimento contrapontístico característico que Perosi utilizou: suspensão ( $7^{\underline{a}}$ maior) resolvendo em consonância imperfeita ( $6^{\underline{a}}$ maior) (ver Figura 12).

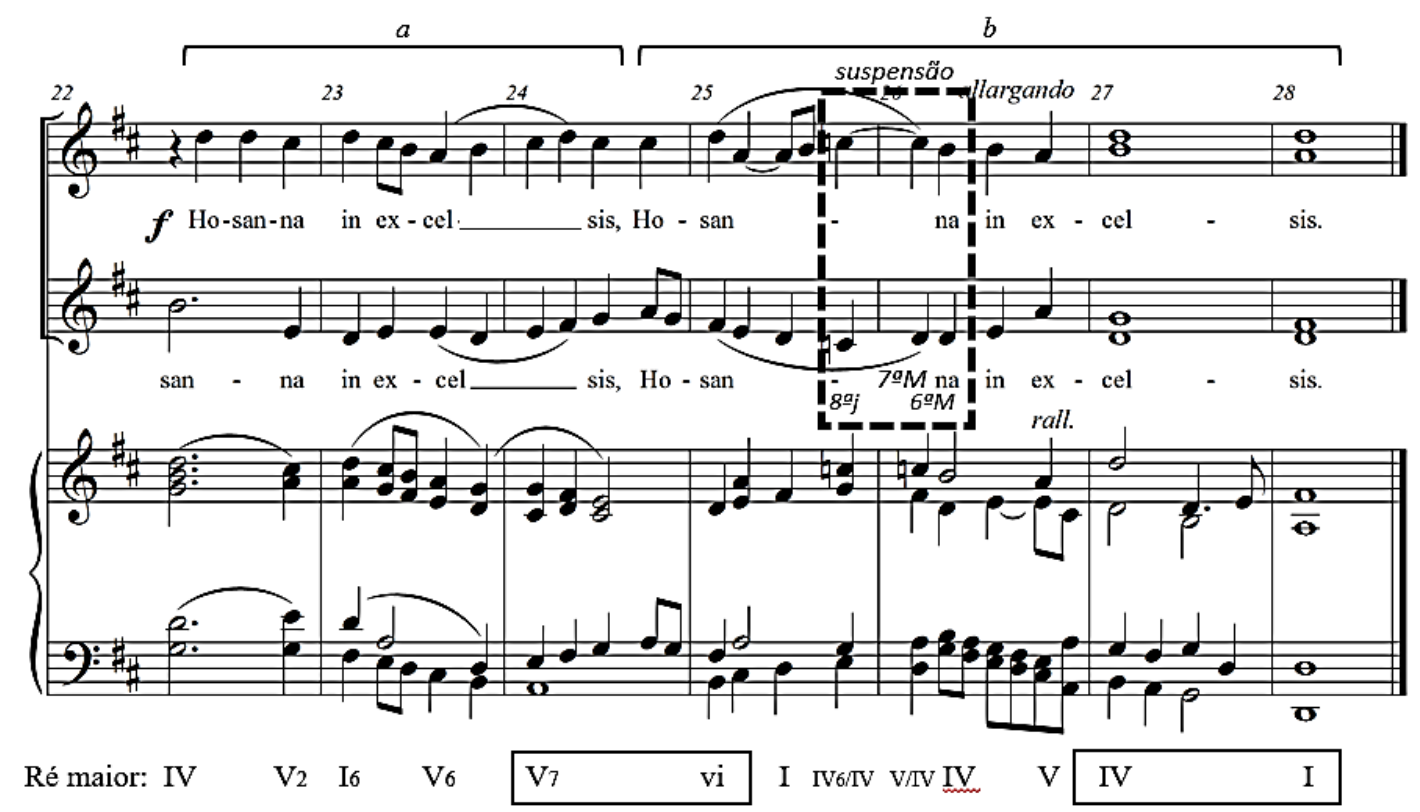

Figura 12 - Sanctus da Missa de A. Nepomuceno, compassos 22 a 28

Neste trecho final, portanto, há identidade entre as duas peças quanto à estrutura formal; há uma equivalência (considerando as naturais distinções entre os procedimentos harmônicos tradicionais em modos maior e menor) quanto ao plano harmônico geral; e uma semelhança quanto ao uso de elementos característicos da polifonia sacra tradicional: o tratamento da dissonância por meio de suspensão e a cadência plagal.

Outro parâmetro que evidencia a proximidade entre os Sanctus de Nepomuceno e Perosi é o da tessitura vocal. Enquanto a tessitura da voz superior é quase igual nas duas peças, variando apena em um semitom no limite superior, a da voz inferior varia em um tom no limite inferior e em uma terça menor no limite superior. A voz inferior de Nepomuceno apresenta-se em um âmbito vocal mais grave que a de Perosi (ver Tabela 7).

\begin{tabular}{|c|c|c|c|c|}
\hline \multirow{2}{*}{} & \multicolumn{2}{|c|}{ Nepomuceno } & \multicolumn{2}{c|}{ Perosi } \\
\cline { 2 - 5 } & $\begin{array}{c}\text { Nota mais } \\
\text { grave }\end{array}$ & $\begin{array}{c}\text { Nova mais } \\
\text { aguda }\end{array}$ & $\begin{array}{c}\text { Nota mais } \\
\text { grave }\end{array}$ & $\begin{array}{c}\text { Nota mais } \\
\text { aguda }\end{array}$ \\
\hline Voz 1 & Mi 3 & Fá\# 4 & Mi 2 & Sol 3 \\
\hline Voz 2 & Lá 2 & Si 3 & Si 1 & Ré 3 \\
\hline
\end{tabular}

Tabela 7 - comparação entre os Sanctus de Nepomuceno e Perosi quanto à tessitura das vozes 
Analisando-se também os intervalos melódicos utilizados pelos compositores nas linhas vocais de seus respectivos Sanctus, observa-se não só a semelhança entre ambos como também se nota para um possível traço da filiação estilística comum ao cantochão e à polifonia clássica (ver Tabela 8).

\begin{tabular}{|c|c|c|c|c|}
\hline \multirow{3}{*}{ Tipo de intervalo } & \multicolumn{4}{|c|}{ Quantidade de intervalos melódicos } \\
\hline & \multicolumn{2}{|c|}{ Nepomuceno } & \multicolumn{2}{|c|}{ Perosi } \\
\hline & Voz 1 & Voz 2 & Voz 1 & Voz 2 \\
\hline Uníssono & 9 & 11 & 5 & 9 \\
\hline $2^{\underline{a}} \mathrm{~m}$ asc. & 9 & 6 & 3 & 3 \\
\hline $2^{\mathrm{a}} \mathrm{m}$ desc. & 8 & 5 & 6 & 7 \\
\hline $2^{\mathrm{a}} \mathrm{M}$ asc. & 12 & 15 & 6 & 7 \\
\hline $2^{\mathrm{a}} \mathrm{M}$ desc. & 13 & 15 & 9 & 11 \\
\hline $3^{\mathrm{a}} \mathrm{m}$ asc. & - & 1 & 3 & 4 \\
\hline $3^{\mathrm{a}} \mathrm{m}$ desc. & 2 & 4 & - & 2 \\
\hline $3^{\mathrm{a}} \mathrm{M}$ asc. & 2 & 1 & 1 & 2 \\
\hline $3^{\mathrm{a}} \mathrm{M}$ desc. & 1 & - & - & 2 \\
\hline $4^{\mathrm{a}} \mathrm{j}$ asc. & 1 & 2 & - & 1 \\
\hline $4^{\mathrm{a}} \mathrm{j}$ desc. & 2 & 3 & 1 & 1 \\
\hline $5^{\mathrm{a}} \mathrm{j}$ asc. & - & 1 & 1 & 1 \\
\hline $5^{\mathrm{a}} \mathrm{j}$ desc. & - & 2 & 1 & 2 \\
\hline
\end{tabular}

Tabela 8 - comparação entre os Sanctus de Nepomuceno e Perosi quanto à quantidade de intervalos melódicos utilizados

Verifica-se, pois, que nenhum dos compositores usa intervalos melódicos maiores que uma 5 $5^{\text {a }}$ justa e que a maior parte das movimentações melódicas ocorrem por grau conjunto: $82 \%$ das vezes em Nepomuceno e $75 \%$ em Perosi. Tanto o canto gregoriano como a polifonia no estilo de Palestrina têm como características esta limitação da gama de intervalos empregados na construção das linhas melódicas. No canto gregoriano utilizam-se somente segunda maior ou menor, terça maior ou menor, quarta justa, quinta justa e raramente emprega se a sexta. Os intervalos aumentados e diminuídos são proscritos (Rose, 1963, p.165). E em Palestrina:

O material melódico de Palestrina é [...] relativamente limitado. Somente os seguintes intervalos são ordinariamente utilizados: as segundas e terças maiores e menores, a quarta justa, a quinta justa, a sexta menor (somente ascendente) e a oitava. [...] Considerados em conjunto, os intervalos empregados por Palestrina são idênticos aos do cantochão, somente tendo sido acrescidos à música polifônica a sexta menor ascendente e a oitava (Jeppesen, 2005, p. 52). 
Sob o aspecto rítmico, as duas peças denotam que as decisões compositivas limitam-se a uma gama muito restrita de valores rítmicos: a duração da unidade de tempo (semínima), sua metade (colcheia) e o seu dobro (mínima). Procedimento este próximo ao utilizado na antiga prática polifônica no estilo palestriniano, em que as figuras com valores inferiores à metade da unidade de tempo eram utilizadas exclusivamente como ornamentação pontual.

Tanto Perosi como Nepomuceno demonstram, assim, alinhar-se à proposta de uma música sacra marcadamente simples e cujo andamento se distancie daqueles típicos da música de concerto e teatral. Deve-se destacar, contudo, que, tanto em Perosi como em Nepomuceno, a apropriação de elementos do cantochão e da polifonia palestriniana (simplicidade rítmica, intervalos melódicos empregados) se faz num contexto claramente tonal. Apesar de aparentemente contraditório, isto denota uma das vertentes do movimento cecilianista: a tentativa de inserção de uma escrita musical sacra de raízes históricas e tradicionais no contexto da expressão harmônica moderna ${ }^{26}$.

\section{6 - Conclusões}

Analisando-se o Sanctus da Missa de Alberto Nepomuceno em sua estrutura interna e em seu contexto histórico, chega-se à conclusão de que ela reflete uma clara influência do Sanctus da Missa Te Deum laudamus do compositor

\footnotetext{
26 “Por volta do final do século XIX, o Movimento Cecilianista começou a perder a força do seu impacto inicial. Em muitas de suas iniciativas, acabou por solidificar-se em um mero formalismo; tornou-se uma organização e não um movimento. [...] O Cecilianismo foi obrigado a ser abalado na procura de seu próprio propósito. Foi necessário reconhecer a outras tendências que foram até então ignoradas, porque as formas de expressão artísticas contemporâneas tiveram que ser consideradas como possibilidades na formação de uma arte eclesiástica." (Fellerer, 1979, p. 193, grifo nossos) O próprio Nepomuceno entendia que o modelo de música sacra exigido por São Pio X não significava um retorno literal a um antigo estilo: “Nestas disposições podem ser enquadradas muitas obras de autores brasileiros, admitindo-se, é verdade, certa elasticidade na interpretação de algumas regras prescritas. Não nos esqueçamos que, mesmo dentro da Escola Romana, dada como modelo, os recursos da composição polifônica variaram de autor para autor. Seria difícil, quase impraticável, para um compositor moderno, manter, por exemplo, na parte referente ao tratamento harmônico, uma pureza absolutamente palestriniana, critério penosíssimo a qualquer mentalidade posterior ao surto da teoria harmônica, logo após descortinada nas exposições teóricas de Rameau e, simultaneamente, nas realizações geniais deJ. S. Bach. Assim, pois, as determinações do "Motu proprio" são referentes, não tanto ao material empregado na composição; istoé, aos movimentos melódico e harmônico, restritos aos poucos intervalos ditos os mais naturais; mas, e principalmente, ao espírito, ao estilo elevado, apropriado ao sentimento religioso." (Nepomuceno apud Bevilacqua, 1946, p. 334, grifo nosso).
} 
italiano Pe. Lorenzo Perosi. Há uma clara semelhança entre as duas obras em diferentes âmbitos. A estrutura formal das frases e da obra como um todo, assim como as diferentes texturas vocal/instrumental utilizadas como elemento de variedade são praticamente idênticas nas duas obras, refletindo assim uma citação de esquemas formais. Além disso, também no nível temático, observa-se que a obra de Nepomuceno reproduz determinados desenhos melódicos e, algumas vezes, até as mesmas relações intervalares presentes em determinados trechos da obra de Perosi, refletindo assim uma citação textual, isto é, uma incorporação de materiais reconhecíveis tomados de outra obra preexistente. Conclui-se, assim, que, no âmbito da forma musical, a obra de Nepomuceno apresenta-se como uma espécie de paráfrase daquela de Perosi; e no âmbito das frases musicais, como uma apropriação mais livre de entidades orgânicas elementares. Entende-se paráfrase como aquele tipo de intertextualidade que descreve a citação reelaborada livremente que não obscurece a obra original e nem lhe altera o sentido; e por entidades orgânicas elementares, o tipo de intertextualidade que descreve as relações entre elementos musicais de proporções reduzidas, ou seja, um elemento musical de pequena dimensão é copiado ou transportado para outro contexto musical, sem perder sua identidade ou efeito sonoro ${ }^{27}$.

As duas obras evidenciam uma filiação estilística comum ao Cecilianismo, sobretudo pela gravidade do andamento, pela simplicidade da expressão musical e pela estilização da polifonia palestriniana, isto é, a apropriação por parte dos dois compositores de um modelo de escrita polifônica (equilíbrio na elaboração dos contornos melódicos, tratamentos das dissonâncias, inteligibilidade do texto etc.) que historicamente se impõe como modelo estético da música sacra católica.

27 Utilizamo-nos aqui sucintamente da abordagem de Corrado (1992), que entende Intertextualidade como conceito ligado ao conjunto de relações demonstráveis no interior de um dado texto que o aproximam a outros textos do mesmo autor ou a modelos literários aos quais pode fazer referência. Também nos valemos da abordagem de Barbosa \& Barrenechea (2003), que, partindo da consideração da música enquanto estrutura composta por sons musicais associados segundo sistemas diversos, propõem algumas categorias de intertextualidade: entidades orgânicas elementares, extrato, idiomática, paráfrase, estilo, paródia e reinvenção. 


\section{Referências}

1. Barbosa, Lucas de Paula e Barrenechea, Lúcia. 2003. A intertextualidade musical como fenômeno. Per Musi, v. 8, p. 125-136.

2. Bas, Julio. 1947. Tratado de la forma musical. Buenos Aires: Ricordi.

3. Bevilacqua, Octavio. 1946. Música sacra de alguns autores brasileiros. Boletim Latino Americano de Música, ano VI, v. 6, p. 331-355.

4. Boulenger. 1949. Doutrina católica: Manual de instrução religiosa para uso dos Ginásios, Colégios e Catequistas voluntários. v. 3. São Paulo: Francisco Alves.

5. Burkholder, J. Peter. 2001. Intertextuality. In: The New Grove Dictionary of Music and Musicians. London: Macmillan.

6. Ciampa, Leonardo. 2006. Don Lorenzo Perosi. Bloomington: AuthorHouse.

7. Corrado, Omar. 1992. Posibilidades intertextuales del dispositivo musical. In: Corrado, O; Kreichman, R.; Malachevsky, J. (Ed.). Migraciones de sentidos: tres enfoques sobre lo intertextual. Santa Fe: Universidad Nacional del Litoral, Centro de Publicaciones.

8. Corrêa, Sergio N. A. 1996. Alberto Nepomuceno: Catálogo Geral. 2. ed.. Rio de Janeiro: Funarte.

9. Documentos sobre a música litúrgica. 2005. São Paulo: Paulus.

10. Fellerer, Karl Gustav. 1979. The History of Catholic Church Music. Westpost: Greenwood Press.

11. Gmeinwieser, Siegfried. 2001. Cecilian Movement. In: The New Grove Dictionary of Music and Musicians. London: Macmillan.

12. Goldberg, Luiz Guilherme D. 2006. Alberto Nepomuceno e a Missa de Santa Cecília de José Maurício Nunes Garcia. In: Anais do VI Encontro de Musicologia Histórica. Juiz de Fora: Centro Cultural Pró-Música, p. 138-172.

13. Jeppesen, Knud. 2005. The style of Palestrina and the dissonance. New York: Dover Music. 
14. Jone, Heriberto. 1943. Compêndioda moral católica. (Trad. R. Fox). Porto Alegre: A Nação.

15. Kieffer, Bruno. 1976. História da música brasileira: dos primórdios ao início do séc. XX. Porto Alegre: Movimento.

16. Lefebvre, Gaspar. 1956. Missal Quotidiano e Vesperal. Paris: Desclée de Brouwer.

17. Museu Villa-Lobos. 2009. Villa-Lobos, sua obra. Rio de Janeiro: Museu VillaLobos.

18. Parente, Pietro. 1955. Diccionario de Teología Dogmática. Barcelona: Editorial Litúrgica Española.

19. Piston, Walter. 1998. Armonía. Cooper City: SpanPress Universitaria.

20. Randel, Michael. 2003. The New Harvard Dictionary of Music. 4 ed. Cambridge and London: The Belknap Press of Harvard University Press.

21. Ratner, Leonard. 2001. Period. In: The New Grove Dictionary of Music and Musicians. London: Macmillan.

22. Reus, João B. 1944. Curso de Liturgia. Petrópolis: Vozes.

23. Rose, Marie. 1963. Canto gregoriano: método de Solesmes. Rio de Janeiro: Instituto Pio X.

24. Salzer, Felix. 1995. Audición estructural: coherencia tonal en la música. 2 v. Barcelona: Labor.

25. Schubert, Guilherme. 1980. Música Sacra no Rio de Janeiro em redor de 1910. In: Brasil 1900-1910, p.11-45. Rio de Janeiro: Biblioteca Nacional.

26. The Catholic Encyclopedia. Disponível em:

<http://www.newadvent.org/cathen/10602a.htm> Acesso em: 07/01/2017.

27. Tomás de Aquino. 2001. Suma Teológica. 10 v. São Paulo: Loyola.

28. Viret, Jacques. 2015. Canto gregoriano: uma abordagem introdutória. Trad. Paulo Valente. Curitiba: Editora UFPR. 
29. Zamacois, Joaquín. 1960. Curso de formas musicales. Barcelona: Labor.

\section{Partituras:}

30. Nepomuceno, Alberto. 1915. Missa: duabus vocibus aequalibus quam in honorem Virginis Immaculatae concinnavit et eminentíssimo Domino Cardinali Arcoverde dicavit. Rio de Janeiro: E. Bevilacqua.

31. Perosi, Lorenzo. 1899. Missa "Te Deum laudamus" ad duas voces facillima comitente Organo. Milão: Ricordi.

\section{Periódicos:}

32. A Notícia, Rio de Janeiro, 29-30/11/1898.

33. A Notícia, Rio de Janeiro, 24-25/03/1916.

34. A União, Rio de Janeiro, 16/05/1915.

35. Correio de Manhã, Rio de Janeiro, 28/01/1907.

36. Correio de Manhã, Rio de Janeiro, 27/07/1908.

37. Correio da Manhã, Rio de Janeiro, 07/07/1915.

38. Gazeta de Notícias, Rio de Janeiro, 13/06/1909.

39. Jornal do Brasil, Rio de Janeiro, 31/08/1904.

40. Jornal do Brasil, Rio de Janeiro, 16/07/1958.

41. O Paiz, Rio de Janeiro, 01/11/1914.

42. O Paiz, Rio de Janeiro, 27/10/1915. 